University of Nebraska - Lincoln

DigitalCommons@University of Nebraska - Lincoln

Mammalogy Papers: University of Nebraska

State Museum

Museum, University of Nebraska State

5-1-1975

\title{
Collections of Recent Mammals in North America
}

Jerry R. Choate

Museum of the High Plains, Fort Hays Kansas State College, Hays, KS

Hugh H. Genoways

Texas Tech University, h.h.genoways@gmail.com

Follow this and additional works at: https://digitalcommons.unl.edu/museummammalogy

Part of the Zoology Commons

Choate, Jerry R. and Genoways, Hugh H., "Collections of Recent Mammals in North America" (1975).

Mammalogy Papers: University of Nebraska State Museum. 49.

https://digitalcommons.unl.edu/museummammalogy/49

This Article is brought to you for free and open access by the Museum, University of Nebraska State at DigitalCommons@University of Nebraska - Lincoln. It has been accepted for inclusion in Mammalogy Papers: University of Nebraska State Museum by an authorized administrator of DigitalCommons@University of Nebraska Lincoln. 


\section{COLLECTIONS OF RECENT MAMMALS IN NORTH AMERICA}

\section{Jerry R. Choate and Hugh H. Genoways}

Mammalogy is the only systematic discipline that has previously undertaken periodic (that is, more than one) surveys of its holdings in North American collections. The first such survey (reported on by Howell, 1923) pertained to mammals in collections as of April of 1922. The report of the second survey (Doutt et al., 1945) summarized collections of mammals in North America as of 1943. The report of the third survey (Anderson et al., 1963) pertained to specimens of mammals in North American collections as of 1962. At that time, it was assumed that to prepare an updated report on North American collection resources of the discipline of mammalogy at a regular interval of about 20 years would be a worthwhile undertaking.

At the annual meeting of the American Society of Mammalogists in June of 1972, the President (J. Knox Jones, Jr.) appointed two new standing committees (the Committee on Systematic Collections, consisting of James H. Brown, Jerry R. Choate, Emmet T. Hooper, Murray L. Johnson, Clyde Jones, David Klingener and James L. Patton; the Committee on Information Retrieval, consisting of Sydney Anderson, Hugh H. Genoways, Robert S. Hoffmann, Clyde Jones, Donald R. Patten, James L. Patton, Henry W. Setzer, and Luis de la Torre) whose charges related to systematic resources. In January of 1973, President Jones and the Chairmen of the two committees (Jerry R. Choate and Sydney Anderson, respectively) met to discuss ways in which systematic resources might be better utilized, to plan future meetings, and to coordinate the work of the two committees. Three fundamental questions were raised at that meeting: What and where are the systematic resources of mammalogy? How should they be maintained? How can they be made more accessible and used more effectively? It was decided that existing data (Anderson et al., 1963) on collections of mammals were sorely out of date, and that another current survey was needed, even though fewer than 20 years had passed since the previous one.

To provide answers to the above questions, the activities of the two committees were combined in the form of an Advisory Committee for Systematic Resources in Mammalogy. The President of the Society and the two Chairmen requested and were granted support (\$9890) from the National Science Foundation (GB 37737) to hold four meetings of the Advisory Committee. Answers to the questions pertaining to maintenance and accessibility of collections of mammals were set forth in the Report and Recommendations . . . of the Advisory Committee (1974). An answer to the question pertaining to the extent and location of systematic resources is contained in this report.

In order to assess the extent and location of collections of mammals in North America, the Advisory Committee prepared a questionnaire consisting of the following questions: 
1. What is the formal name (if any), address, and standard abbreviation (if any) of your private or institutional collection?

2. What is the name, address, and telephone number of the person directly responsible for the collection?

3. Approximately how many specimens of Recent (not fossil) mammals were in the collection as of 1 July 1973? Approximately how many are not yet catalogued? As of what date?

4. How many holotypes are in the collection? As of what date? Has a catalogue or list of those types been published? If so, please give citation.

5. Are specimens in the collection stored in containers adequate to protect them from damage?

6. What geographic areas are best represented in the collection?

7. What systematic groups are best represented in the collection?

8. What special preparations are represented (if possible, give approximate numbers of specimens)? Specimens in alcohol? Specimens in buffered formalin? Skeletons? Injected anatomical preparations? Karyotypic preparations? Microscopic preparations? Mounted specimens? Electrophoretograms? Specimens of known age? Domestic animals? Bacula and/or glans? Segregated teaching collection? Others?

9. Approximately what percent of skulls and other skeletal materials are cleaned and individually enclosed in appropriately labeled vials or other containers?

10. Are original field notes and field catalogues routinely preserved with the collection?

11. What special files are maintained with the collection (if possible, give approximate numbers)? Photographs of specimens? Photographs of habitats? Color transparencies? Photomicrographs? Tape recordings? $2 \times 2$ slides? Lantern slides? Motion pictures? X-ray photographs? Others?

12. Are specimens recorded in a catalogue arranged numerically? by systematic groups? by geographic areas? by collectors? others?

13. Have the museum catalogues ever been microfilmed? If so, on what date? To what catalogue number? Would permission be granted to microfilm them if support were found to microfilm all catalogues?

14. Are curatorial practices and documentation procedures standarized for the collection? Are they available in written form?

15. Do you have immediate plans for active development of some form of electronic data processing as a means of assisting in collection management and information retrieval?

16. Does the collection include specimens cited in the literature as being in a different collection (for example, a formerly private collection now deposited in an institutional collection)? What previously cited collections have been combined with yours?

17. Will specimens be loaned for study (this presumes that loans are usually made to institutions rather than individuals and that adequate insurance will be carried during shipment; the loan of holotypes is not expected)?

18. Approximately how many such loans have been made in the past two years? How many specimens would you estimate were involved in those loans?

19. Is the collection in sufficient order to permit use by visiting investigators? Is someone usually available to aid an investigator who wishes to use the collection? Is it usually necessary to make arrangements in advance?

20. Is a special systematic library maintained near the collection? Do you regard the library as poor? fair? good? excellent? Is the library available to persons who might visit the collection?

21. Who are the professional scientists at your institution who use the collection, and what are their specialities?

22. In the past two years, how many students at your institution (if applicable) have used the collection directly in their thesis projects? How many for other projects? 
How many students have used the collection indirectly (such as for deposition of voucher specimens) in their thesis projects? How many for other projects?

23. Estimate the number of visitors who have used the collection in the past two years: professional mammalogists? visiting graduate students? other professional scientists? state or federal employees? others?

24. In your estimation, how is the collection used (give answer in percent of total use)? Professional research? Student research? Teaching? Public service? Exhibition? Other uses? Comments?

25. What do you regard as the primary goal of the collection (for example, research, teaching, exhibition, and others)?

26. Does your institution produce a periodic or annual report in which information on the collection routinely is presented? If so, give the most recent citation.

27. This questionnaire was completed by whom? Title? Date?

Copies of the questionnaire were mailed to: a) curators or owners of all known or suspected collections; b) all U.S. National Parks, Monuments, Areas, and Sites; c) all persons who responded to requests for information placed in volumes 54(3) and 55(1) of the Journal of Mammalogy; d) all state fish and wildlife or conservation departments. A total of 824 questionnaires was mailed and 565 (69 percent) replies were received. Based on these replies, 289 collections of 100 or more mammals and 34 of fewer than 100 mammals are known to exist in North America. Questionnaires were not returned for 65 of the collections previously reported (Anderson et al., 1963), and their present status is not known.

Data compiled from returned questionnaires indicate that almost 2,374,000 specimens of mammals are catalogued and available for study in North American collections of more than 100 specimens, and that an additional 100,000 specimens await cataloguing. Nonreporting collections listed in the 1963 survey and reporting collections of fewer than 100 specimens together contained an estimated 68,000 specimens. Accordingly, the total holdings of North American collections of mammals as of 31 December 1973 was approximately 2,542,000 specimens.

Eighty-four percent of the catalogued specimens presently available are housed in the 38 North American collections of 10,000 or more mammals. These collections, listed in descending order of size in Table 1, have grown at an average rate of more than 62,000 specimens per year since the 1963 survey. Two of these 38 collections are in Canada, one is in México, and the remainder are in 22 different states with all regions of the United States represented. Of the 5726 reported holotypes of mammals contained in North American collections, all but 25 (22 at the British Columbia Provincial Museum and one each at Oklahoma State University, University of Wisconsin-Madison, and University of Wisconsin-Stevens Point) are housed at one or another of the 38 largest collections; slightly more than 50 percent of the holotypes are in the combined collections of the National Museum of Natural History and the Bird and Mammal Laboratories of the U.S. Fish and Wildlife Service.

The historical development of North American collections of mammals is summarized in Table 2. Eighty-one more collections were reported in the 
TABLE 1.-North American Collections of 10,000 or more specimens.

\begin{tabular}{|c|c|c|c|}
\hline Institution & $\begin{array}{l}\text { Number of } \\
\text { specimens }\end{array}$ & $\begin{array}{c}\text { Growth/year } \\
\text { since } 1963\end{array}$ & $\begin{array}{c}\text { Number of } \\
\text { holotypes }\end{array}$ \\
\hline \multicolumn{4}{|l|}{ National Museum of Natural History and } \\
\hline Bird and Mammal Laboratories & 475,000 & 17,000 & 3000 \\
\hline American Museum of Natural History & 240,000 & 4000 & 950 \\
\hline University of California at Berkeley & 144,000 & 1400 & 330 \\
\hline University of Kansas & 132,000 & 4200 & 118 \\
\hline University of Michigan & 111,800 & 480 & 122 \\
\hline Field Museum of Natural History & 110,000 & 1700 & 484 \\
\hline Harvard University & 69,000 & 1900 & 147 \\
\hline Royal Ontario Museum, Canada & 68,360 & 3836 & 8 \\
\hline Carnegie Museum of Natural History & 55,000 & 1500 & 30 \\
\hline University of Illinois & 48,701 & 2280 & 15 \\
\hline National Museum of Natural Sciences, Canada & 42,500 & 1179 & $61^{*}$ \\
\hline University of New Mexico & 35,000 & 2100 & 1 \\
\hline University of Utah & 27,800 & 880 & 40 \\
\hline Texas A \& M University & 27,000 & 1880 & 36 \\
\hline Texas Tech University & 23,000 & 2180 & 1 \\
\hline San Diego Natural History Museum & 22,870 & 187 & 89 \\
\hline Michigan State University & 22,074 & 1417 & $\mathbf{0}$ \\
\hline University of Arizona & 22,000 & 1370 & 0 \\
\hline Los Angeles County Museum of Natural History & 21,500 & - & no report \\
\hline Philadelphia Academy of Natural Sciences & 21,000 & - & 157 \\
\hline California Academy of Sciences & 20,745 & 775 & 19 \\
\hline Cleveland Museum of Natural History & 18,600 & - & 0 \\
\hline Louisiana State University & 18,518 & 952 & 22 \\
\hline University of California, Los Angeles & 18,460 & - & 48 \\
\hline University of Connecticut & 16,200 & 1420 & 0 \\
\hline University of Puget Sound & 16,000 & 500 & 0 \\
\hline University of Florida & 15,598 & 760 & 5 \\
\hline University of Colorado & 14,100 & 1110 & 1 \\
\hline Cornell University & 14,000 & 300 & 0 \\
\hline Instituto de Biologia, México & 13,633 & 763 & 14 \\
\hline University of Alaska & 13,000 & 800 & 0 \\
\hline University of Minnesota & 12,500 & 527 & 0 \\
\hline Bernice P. Bishop Museum & 12,000 & 1165 & 6 \\
\hline Fort Hays Kansas State College & 12,000 & 1150 & 0 \\
\hline University of Nevada, Las Vegas & 11,000 & 1060 & 0 \\
\hline University of Oklahoma & 11,000 & 800 & 0 \\
\hline California State University, Fresno & 10,000 & - & 0 \\
\hline Midwestern University & 10,000 & 900 & 0 \\
\hline Total & $1,975,959$ & 62,471 & $5701^{* *}$ \\
\hline
\end{tabular}

* Including three holotypes presently at University of British Columbia.

** British Columbia Provincial Museum possesses 22 and Oklahoma State University, University of Wisconsin-Madison, and University of Wisconsin-Stevens Point each possess one holotype giving a total of 5726 holotypes in North American collections (Los Angeles County Museum of Natural History, not reporting). 
TABLE 2.-Historical development of North American collections of mammals.

\begin{tabular}{|c|c|c|c|c|}
\hline Statistics & 1922 & 1943 & 1962 & 1973 \\
\hline Number of collections listed & 77 & 257 & 307 & 388 \\
\hline Number of specimens listed $(\times 1000)$ & 410 & 939 & 1586 & 2542 \\
\hline Number of private collections & 40 & 91 & 43 & 36 \\
\hline $\begin{array}{l}\text { Number of specimens in private } \\
\text { collections }(\times 1000)\end{array}$ & 32 & 78 & 28 & 24 \\
\hline Number of public collections & 37 & 166 & 265 & 352 \\
\hline $\begin{array}{l}\text { Number of specimens in public } \\
\text { collections }(\times 1000)\end{array}$ & 378 & 862 & 1558 & 2518 \\
\hline $\begin{array}{l}\text { Number of collections of } 20,000 \\
\text { specimens or more }\end{array}$ & 5 & 10 & 15 & 21 \\
\hline $\begin{array}{l}\text { Number of collections of } \\
10,000-19,999 \text { specimens }\end{array}$ & 1 & 5 & 5 & 17 \\
\hline Number of collections of 5000-9999 & 3 & 4 & 19 & 29 \\
\hline Number of collections of $1000-4999$ & 21 & 43 & 66 & 104 \\
\hline
\end{tabular}

survey just completed than in the survey published in 1963. Most of these represent new collections, but a few are simply the result of more intensive sampling. There are fewer private collections of mammals, and fewer specimens in those collections, at this time than at any time since data on North American collections have been available.

Conversely, the rates at which both the number of collections and the total number of specimens in those collections are growing have increased; Anderson et al. (1963) gave the percent increase in number of collections and number of specimens in the 20-year period between 1943 and 1962 as 20 and 69, respectively. This means that North American collections of mammals were growing at a rate of $3 \frac{1}{2}$ percent per year between 1943 and 1962 . In the 10year period between 1963 and 1973, the number of collections increased by 31 percent and the number of specimens by 60 percent. Therefore, the rate of growth of North American collections during this period has accelerated to $5^{1 / 2}$ percent per year. The most rapid growth since the last survey is in collections of 10,000 to 19,999 specimens and collections of 1000 to 4999 specimens.

\section{SuRvey of Collections}

Collections of mammals included in this survey are arranged in three lists: reporting collections of 100 or more specimens; reporting collections of fewer than 100 specimens plus those collections reported in the 1963 survey for which questionnaires were not returned; institutions suspected of housing collections but for which no data could be obtained.

In the following list, data for reporting public collections of more than 100 specimens are arranged as below.

Name (including unique acronym) and address of collection. Number of specimens catalogued (plus number not yet catalogued); number of holotypes; 
geographic areas best represented; systematic groups best represented; significant special preparations; whether or not field notes are available; significant special files; how specimens are catalogued (if collection includes more than 1000 specimens); whether or not the collection includes specimens cited in the literature as being in different collections; whether or not a teaching collection is available (number of specimens); primary goal and/or use of the collection; person in charge of collection; person who completed the questionnaire. A unique acronym is provided for each collection to aid in their identification in future studies. These acronyms will be particularly useful if the proposed national information retrieval network for mammalogy becomes a reality.

The arrangement for private collections is as above except that the address of the owner is given at the end of the entry.

\section{Canada}

\section{Alberta}

1. University of Alberta, Museum of Zoology (UAMZ), Edmonton. $6700(+1100)$; Alberta, Saskatchewan, and Manitoba; Soricidae, Lagomorpha, and Rodentia; including 100 skeletons, specimens of known age, and "many" bacula and/or glans; field notes; specimens recorded in catalogues arranged numerically and by systematic groups; includes formerly private collections of J. D. Soper, J. E. Moore, R. Lister, and at least part of the collection of W. Rowan; segregated teaching collection (200 specimens); collection used primarily in teaching and secondarily in research; reported by N. Panter, Curator.

\section{British Columbia}

2. University of British Columbia (UBC), Vertebrate Museum, Vancouver. 9525; 3 holotypes soon to be transferred to the National Museum of Natural Sciences in Ottawa; British Columbia, Northwest Territory, Alaska, and Alberta; Insectivora, Chiroptera, Lagomorpha, Rodentia, and Carnivora; including 150 skeletons; specimens recorded in catalogues arranged numerically and by systematic groups; includes formerly private collections of Kenneth Racey, I. McT. Cowan, and A. C. Brooks; collection used primarily in research; reported by J. Mary Taylor, Director.

3. British Columbia Provincial Museum (BCPM), Victoria V8W 1A1. 9000; 22 holotypes; British Columbia; some field notes; photographic file; systematic card file; reported by C. J. Guiguet, Curator, and R. W. Campbell, Assistant Curator, Bird and Mammal Division.

\section{Manitoba}

4. Manitoba Museum of Man and Nature (MMMN), 190 Rupert Avenue, Winnipeg R3B 0N2. 6000; Manitoba; Rodentia, Insectivora, and Carnivora; including 300 skeletons; field notes; special files, including 120 photographs of specimens or habitats; specimens recorded in catalogues arranged numerically, by systematic groups, and by geographic areas; collection used primarily in research and secondarily in teaching and exhibition; reported by Robert E. Wrigley, Curator of Higher Vertebrates.

5. University of Manitoba (UMAN), Department of Zoology, Winnipeg. $1500(+500)$; Manitoba; Rodentia and Insectivora; specimens recorded in a catalogue arranged numerically; including 1200 or more specimens from the Stuart Criddle Collection; segregated teaching collection; collection used about equally in research and teaching; reported by William O. Pruitt, Jr., Professor of Zoology. 
6. Whiteshell Nuclear Research Establishment (WNRE), Environmental Research Branch, Pinawa. 700; southeastern Manitoba; Rodentia and Insectivora; field notes; collections used entirely in research; reported by Stuart Iverson.

\section{New Brunswick}

7. New Brunswick Museum (NBM), 277 Douglas Avenue, Saint John. $1018(+20)$; New Brunswick; Rodentia and Insectivora; including 150 mounted specimens; specimens recorded in catalogues arranged numerically and by systematic groups; collection used about equally in exhibition and research; person in charge is Stanley W. Gorham; reported by D. S. Christie, Head of Natural Science Department.

8. N. Ray Brown Collection (NRBC); 600; southeastern Ontario and central New Brunswick; Rodentia and Insectivora; collection used primarily in teaching, and is willed to the Canadian National Museum of Natural Sciences; reported by owner (address: Faculty of Forestry, University of New Brunswick, Fredricton).

\section{Nova Scotia}

9. Acadia University Museum (AUM), Wolfville. 1367; maritime provinces of Canada; field notes; specimens recorded in catalogues arranged numerically, by systematic groups, by geographic areas, and by collectors; collection used primarily in teaching; reported by Cyril K. Caldwell, Museum Technician.

10. Nova Scotia Museum (NSM), 1747 Summer Street, Halifax. $720(+100)$; Nova Scotia; Soricidae, Vespertilionidae, Cricetidae, and Zapodidae; including 220 specimens in alcohol; field notes; special files, including 300 photographs of habitats and a card file of 2600 Nova Scotian mammals (especially shrews and rodents) in other collections; including bats previously housed at Acadia University; collection used primarily in reference; reported by Frederick Scott, Curatorial Assistant of the Zoology Unit.

\section{Ontario}

11. Algonquin Provincial Park (APP), Ministry of Natural Resources, Box 219, Whitney K0J 2M0. 354; local Rodentia and Insectivora; collection used primarily in interpretation; reported by Daniel F. Brunton, Regional Environmental Planner.

12. Ronald C. Brooman Collection (RCBC); 165; southern Ontario; Insectivora and Rodentia; field notes; collection presently receiving little use; reported by owner (address: RR \#1, Waterloo N2K 2B3).

13. Carleton University, Museum of Zoology (CUMZ), Ottawa K1S 5B6. 8500 $(+4500)$; southern Ontario, Uganda, and Nigeria; Sciuridae, Cricetidae, Zapodidae, Muridae, Chiroptera, and Soricidae; including 500 specimens in alcohol, 1000 skeletons, 300 specimens of known age, and thousands of ectoparasites (especially fleas); field notes; specimens recorded in catalogues arranged numerically and by collectors; including Donald A. Smith Collection; collection used primarily in teaching; reported by Donald A. Smith, Curator and Associate Professor of Biology.

14. Chemical Control Research Institute (CCRI), 25 Pickering Place, Ottawa K1A 0H3. 500; Manitoba, England, and central Ontario; Soricidae; field notes; entire collection previously at Forest Entomology Laboratory, Winnipeg; collection used primarily in research; reported by C. H. Buckner, Project Leader.

15. National Museum of Natural Sciences (NMC), Ottawa K1A 0M8. 42,500 $(+1000)$; 58 holotypes; northern North America; Rodentia and Carnivora; including 800 specimens in alcohol, skeletons, karyotypic preparations, mounted specimens, 50 domestic animals, and bacula and/or glans; field notes; specimens recorded in a catalogue arranged numerically; collection used primarily in research; reported by C. G. van Zyll de Jong, Curator of Mammals. 
16. Rondeau Provincial Park (RPP), RR \#1, Morpeth. $200(+800)$; local representation; field notes; collection used primarily in documentation and interpretation; reported by Paul D. Pratt, Visitor Services Supervisor.

17. Royal Ontario Museum (ROM), 100 Queens Park, Toronto M5S 2C6. 68,360 $(+5000) ; 8$ holotypes; Guyana, eastern Canada, Philippines, Uganda, Kenya, Madagascar, Malaysia, Rhodesia, Camaroun, and Colombia; Chiroptera, Mustelidae, Alces, Felidae, and Canidae; including 15,000 specimens in alcohol, 50 specimens in buffered formalin, 1500 skeletons, 180 karyotypic preparations, 1000 microscopic preparations, 200 mounted specimens, 500 specimens of known age, 100 domestic animals, and 250 bacula and/or glans; field notes; special files, including 10,000 photographs of specimens, 10,000 photographs of habitats, photomicrographs, 15,000 $2 \times 2$ slides and color transparencies, 3 motion pictures, and $200 \mathrm{x}$-ray photographs; specimens recorded in catalogues arranged numerically, by systematic groups, and by geographic areas; including previously cited private collections of W. E. Saunders, J. H. Fleming, J. A. Munro, C. B. Garret, G. E. Beare, J. H. Garnier, A. W. F. Banfield, and Eli Davis; segregated teaching collection (200 specimens); collection used primarily in research; reported by R. L. Peterson, Curator of Mammalogy.

18. University of Western Ontario (UWOC), Department of Zoology, London N6A 3K7. $850(+75)$; southern Ontario and southern British Columbia; Sciurus carolinensis and Tamiasciurus hudsonicus; collection used entirely in teaching; reported by D. M. Scott, Professor of Zoology.

\section{Quebec}

19. MeGill University, Redpath Museum (MURM), P.O. Box 6070, Station A, Montreal H3C 3G1. 1500; Canada and East Africa; field notes; collection used primarily in teaching; reported by Mrs. D. Alison, Zoology Technician.

\section{Saskatchewan}

20. University of Saskatchewan-Regina (USRC), Biology Department, Regina. 250; synoptic regional representation; field notes; collection used primarily in teaching; reported by D. M. Secoy, Associate Professor of Biology.

21. University of Saskatchewan-Saskatoon (USSC), Department of Biology, Saskatoon S7N 0W0. $2802(+24)$; Saskatchewan; Rodentia; field notes; specimens recorded in catalogues arranged numerically and by systematic groups; collection used about equally in teaching and research; reported by William J. Maher, Associate Professor of Biology.

\section{Mexico}

22. Escuela Nacional de Ciencias Biologicas (ENCB), Instituto Politecnico Nacional, México 17, D. F. Maintains an important collection, perhaps 6000 or more, from Mexico. Person in charge is Ticul Alvarez S.

23. Universidad Nacional Autónoma de México (UNAM), Instituto de Biología, Ciudad Universitaria, Apartado Postal 70233, México 20, D. F. 13,633 (+600); 14 holotypes; Mexico, Argentina, and Brazil; Rodentia and Chiroptera; including 1372 specimens in alcohol, 149 skeletons, and 100 mounted specimens; field notes; specimens recorded in catalogues arranged numerically, by systematic groups, and by collectors; collection used primarily in research and secondarily in teaching; reported by Bernardo Villa Ramirez.

\section{United States}

\section{Alabama}

24. Alabama Department of Conservation and Natural Resources (ADCC), Game and Fish Division, 64 Union Street, Montgomery, 36104. 120; primarily a synoptic collection from Alabama; collection used primarily in education and public service; reported by James E. Keeler, Chief of Game Research. 
25. University of Alabama (UAMC), Museum of Natural History, University, 34586. 5000; southeastern United States; Rodentia; field notes; specimens recorded in a catalogue arranged numerically; collection used primarily in teaching; reported by Herbert Boschung, Director of Museum and Professor of Biology.

26. University of South Alabama (USA), Natural History Collections, Mobile, 36688 . 1010; southeastern United States (primarily Alabama); Chiroptera, Soricidae, and Cricetidae; field notes; specimens recorded in a catalogue arranged numerically; including specimens formerly in the collection at the Mississippi State College for Women; segregated teaching collection; collection used primarily in research and secondarily in teaching and public service; reported by Donald W. Linzey, Curator.

\section{Alaska}

27. Alaska Department of Fish and Game, Division of Game (DGA), 1300 College Road, Fairbanks, 99701. 5000; interior and western Alaska; primarily Lynx but also Phocidae; including skeletons (primarily skulls) and bacula and/or glans; field notes; specimens recorded in catalogues arranged numerically, by systematic groups, and by geographic areas (in part); collection is being actively used in research, but eventually will be transferred to the University of Alaska Museum; reported by Richard H. Bishop, Research Coordinator.

28. Naval Arctic Research Laboratory (NARL), Barrow, 99723. 123; Alaskan Arctic coastal plain; Cricetidae, Mustelidae, and Phocidae; collection used primarily in exhibition; reported by L. S. Underwood, Assistant Director for Science.

29. University of Alaska Museum (UAM), Fairbanks, 99701. 13,000 (+3000); Alaska; 575 Lepus americanus, 110 Spermophilus parryi, 400 Tamiasciurus hudsonicus, 330 Castor, 1200 Clethrionomys, 1000 Microtus (especially M. miurus and M. oeconomus), 360 Ondatra, 3000 Canis lupus, 900 Gulo, 720 Martes americana, 770 Mustela vison, and 500 Alopex; including 2000 skeletons, microscopic preparations, mounted specimens, 150 specimens of known age (of which 100 are Canis lupus), 2000-3000 bacula and/or glans, and reproductive tracts of Tamiasciurus; field notes; specimens recorded in catalogues arranged numerically and by systematic groups; including specimens formerly in the collection of the Alaska Department of Fish and Game and in the private collections of Otto W. Geist and William O. Pruitt; segregated teaching collection (175 specimens); collection used primarily in research and secondarily in teaching; reported by Brina Kessel, Curator of Terrestrial Vertebrates.

\section{Arizona}

30. Arizona State University (ASU), Department of Zoology, Tempe, 85281. 6700 $(+500)$; Arizona; Rodentia; field notes; specimens recorded in catalogues arranged numerically and by systematic groups; collection used primarily in research and secondarily in teaching; reported by Ronald R. Clothier, Associate Professor of Zoology.

31. Grand Canyon National Park (GCNP), Box 129, Grand Canyon, 86023. 750; 75 percent from Grand Canyon National Park and Monument, and 19 percent from Monument Valley (Arizona and southern Utah); Cricetidae (30 percent) and Sciuridae (30 percent); including materials collected in the Rainbow Bridge-Monument Valley Expedition of 1933, although reports of the expedition do not indicate so; collection used primarily for documentation and secondarily in interpretation and research; reported by Louise M. Hinchliffe, Museum Technician.

32. Museum of Northern Arizona (MNA), P.O. Box 1389, Flagstaff, 86001. 3000; northern Arizona (emphasis on Grand Canyon region); Rodentia; including 500 skeletons; field notes; specimens recorded in a catalogue arranged numerically; collection used primarily in research; person in charge is Steven W. Carothers, Curator of Zoology; reported by Elizabeth Aitchison, Secretary-Technician. 
33. Northern Arizona University (NAU), Museum of Vertebrates, Box 5640, Flagstaff, 86001. $2658(+400)$; Arizona, Sinaloa, and Nayarit; Chiroptera and Heteromyidae; including 200 specimens in alcohol, 100 specimens in buffered formalin, and 150 skeletons; specimens recorded in a catalogue arranged numerically; collection used primarily in teaching; reported by Gary C. Bateman, Assistant Professor of Biology.

34. Organ Pipe Cactus National Monument (OPCNM), P.O. Box 38, Ajo, 85321. 298; local Rodentia; reported by Edward C. Rodriguez, Jr., Superintendent.

35. Southwestern Research Station (SRS) of the American Museum of Natural History, Portal, 85632. 100 specimens collected locally and used primarily as a reference for identification by visiting researchers; reported by Vincent D. Roth.

36. University of Arizona, Arizona Archaeological Center (UAAC), 6th and Martin Street, Tucson, 85721. 500; southwestern United States; synoptic representation excepting Chiroptera; collection used primarily in zooarchaeological interpretation and research; reported by Stanley J. Olsen, Curator of Zooarchaeology and Professor of Anthropology.

37. University of Arizona (UA), Department of Biological Sciences, Tucson, 85721. $22,000(+300)$; Arizona and Sonoran Desert region of Mexico; New World Chiroptera and Heteromyidae; including 2000 specimens in alcohol and 600 skeletons; field notes; specimens recorded in catalogues arranged numerically, by systematic groups, and by geographic areas, collection used primarily in research and secondarily in teaching; person in charge is E. Lendell Cockrum; reported by Edward L. Roth, Graduate Curator for Mammals.

\section{Arkansas}

38. Arkansas State University (ASUZC), Division of Biological Sciences, State University, 72467. $500(+150)$; Arkansas and southeastern Missouri; Rodentia, Insectivora, and Chiroptera; including 100 specimens in alcohol, 350 skeletons, and 300 brains (in buffered formalin or alcohol) of tropical bats; field notes; segregated teaching collection (50 specimens); collection used primarily in research; reported by V. Rick McDaniel, Assistant Professor of Zoology.

39. University of Arkansas (UARK), Zoology Department, Fayetteville, 72701. 1600 $(+250)$; Arkansas; Cricetidae, Canidae, and Felidae; including 350 skulls of Canis latrans and Lynx rufus; specimens recorded only by year of accession; collection used primarily in research; reported by John A. Sealander, Professor of Zoology.

40. University of Arkansas at Little Rock (UALR), Department of Biology, Little Rock, 72204. $300(+300)$; Arkansas and Michigan; Mustelidae; segregated teaching collection; collection used primarily in teaching and secondarily in research; reported by Gary A. Heidt, Assistant Professor of Biology.

\section{California}

41. California Academy of Sciences (CAS), Golden Gate Park, San Francisco, 94118. 20,745 (+185); 19 holotypes; western United States (California, Oregon, Washington, and Arizona), eastern Pacific, Mexico (Baja California and Oaxaca), Alaska, East Africa, and Manchuria; Odontoceti, Chiroptera, Pinnipedia, Bovidae, Sciuridae, Heteromyidae, Cricetidae, and Lagomorpha; including 1135 specimens in alcohol and 555 skeletons; field notes; special files, including 1500 photographs of specimens, 500 photographs of habitats, 5000 color transparencies, and 5 motion pictures; specimens recorded in catalogues arranged numerically and by systematic groups; including the collection (CAS-SU) formerly at Stanford University and the formerly private collections of Anatole S. Loukashkin, Hubert O. Jenkins, and W. W. Price; collection used about equally in research and teaching; person in charge is Robert T. Orr, Curator and Associate Director; reported by Jacqueline Schonewald, Scientific Assistant.

42. California Polytechnic State University (CPSU), Biological Sciences Department, San Luis Obispo, 93407. $1250(+50)$; local Pinnipedia (especially Zalophus), Sciurus 
griseus, Thomomys, Dipodomys, Cricetidae, Delphinidae, and Enhydra; including 100 bacula and/or glans and some dried, disembowled, previously formalinized specimens from Panama; specimens recorded in catalogues arranged numerically and by systematic groups; segregated teaching collection (500 specimens); collection used primarily in teaching; reported by A. I. Roest, Professor of Biology.

43. California State College, Stanislaus (CSCS), Department of Biological Sciences, Turlock, 95380. $1000(+300)$; California; Chiroptera and Rodentia; including 100 specimens fixed in formalin and stored in alcohol, 200 karyotypic preparations, and 100 bacula and/or glans; specimens recorded in catalogues arranged numerically and by systematic groups; collection used primarily in teaching; reported by Daniel F. Williams, Assistant Professor of Biological Sciences.

44. California State Polytechnic University (CSPU), Biological Sciences Department, Pomona, 91768. 837; southern California; Rodentia (Peromyscus, Perognathus, and Dipodomys); collection is used primarily in teaching; reported by Glenn R. Stewart, Professor of Zoology.

45. California State University, Fresno (CSUF), Department of Biology, Fresno, 93740. 10,000; San Joaquin Valley, west slope of the Sierra Nevada, and the Mojave Desert; Geomyidae, Dipodomys, Aplodontia, and Sciurus; field notes; specimens recorded in a catalogue arranged numerically; collection previously used primarily in teaching, but increasingly used in research; reported by David L. Chesemore, Assistant Professor of Biology.

46. California State University, Fullerton (CSFL), Department of Biological Sciences, Fullerton, 92634. $700(+200)$; primarily local Rodentia and representatives of Australian Marsupialia; field notes; segregated teaching collection; collection used primarily in teaching; reported by James Dale Smith, Associate Professor of Zoology.

47. California State University, Long Beach (CSLB), Biology Department, Long Beach, 90840. $9000(+3000)$; southwestern United States (especially southern California) and northwestern Mexico; Heteromyidae and Chiroptera (57 species); including 500 specimens in alcohol from Sonora, Sinaloa, Baja California, and Nayarit; field notes; specimens recorded in catalogues arranged numerically and by systematic groups; including some specimens formerly in Ross Hardy Collection; collection used primarily in teaching; reported by David George Huckaby, Assistant Professor.

48. California State University, Los Angeles (CSULA), Biology Department, Los Angeles, 90032. 1108; synoptic representation from southern California; specimens recorded in catalogues arranged numerically and by systematic groups; including formerly private collection of Jack C. Von Bloeker; segregated teaching collection (400 specimens); collection used primarily in teaching; person in charge is Daniel S. Fertig; reported by Paul C. Moore, Technical Assistant.

49. California State University, Sacramento (CSUS), Museum of Natural History, Sacramento, 95819. $1800(+20)$; California; Cricetidae, Sciuridae, and Leporidae; field notes; specimens recorded in catalogues arranged numerically and by systematic groups; segregated teaching collection ( 250 specimens); collection used primarily in teaching; reported by James D. Tilley, Curator and Preparator.

50. Chico State University (CSUC), Biology Department, Chico, 95926. $3800(+40)$; northern California; Sciuridae (especially Eutamias); including 500 karyotypic preparations, 600 bacula and/or glans, and female genital bones; field notes; special files, including 200 $2 \times 2$ slides; specimens recorded in catalogues arranged numerically and by systematic groups; collection used about equally in research and teaching; reported by Dallas A. Sutton, Professor of Biology.

51. Death Valley National Monument (DVNM), Death Valley, 92328. $181(+40)$; Death Valley and southwestern Great Basin; Ovis canadensis; field notes; collection used primarily in public service; reported by G. Frank Ackerman, Interpretive Specialist. 
52. Hastings Natural History Reservation (HNHR), Star Route, Box 8, Carmel Valley, 93924. 179; local Spermophilus and Peromyscus; field notes; collection used entirely in teaching; reported by Dr. John Davis, Lecturer in Zoology and Associate Research Zoologist.

53. Milton Hildebrand Collection (MHC); $1300(+25)$; world-wide representation, with emphasis on diversity of geographic areas, systematic groups, and methods of preparation; including 1000 skeletons, several injected anatomical preps, 15 mounted skeletons, 25 specimens of known age, 50 domestic animals, many bacula and/or glans, freeze-dried dissections, alizarin skeletons, paraffin-cartilage preps, and sectioned teeth; specimens recorded in catalogues arranged numerically and by systematic groups; segregated teaching collection; collection used primarily in teaching and secondarily in research; reported by owner (address: Department of Zoology, University of California, Davis, 95616).

54. Humboldt State University (HSU), Department of Biology, Arcata, 95521. 2500 $(+200)$; northern California; Rodentia; specimens recorded in a catalogue arranged numerically; segregated teaching collection (200 specimens); collection used primarily in teaching and secondarily in research; reported by Timothy E. Lawlor, Chairman and Associate Professor.

55. Occidental College, Moore Laboratory of Zoology (OCMLZ), Los Angeles, 90041. $900(+200)$; Mexico; Chiroptera and Rodentia; field notes; segregated teaching collection (100 specimens); collection used primarily in teaching; reported by Luis Felipe Baptista, Curator.

56. Pacific Union College (PUC), Department of Biology, Angwin, 94508. 1500; Napa and Mendocino counties of northern California; Rodentia; field notes; older specimens recorded in a catalogue arranged numerically, but newer specimens recorded only by annual accessions; including personal collection of D. V. Hemphill; collection used primarily in teaching; reported by Donald V. Hemphill, Professor of Biology.

57. San Bernardino County Museum (SBCM), 2024 Orange Tree Lane, Redlands, 92373. 372; field notes; collections used primarily in education through exhibition; person in charge is Gerald A. Smith, Director; reported by Eugene A. Cardiff, Curator of Natural History.

58. San Diego Natural History Museum (SDSNH), Balboa Park, P.O. Box 1390, San Diego, 92112. 22,870 $(+40)$; 89 holotypes; southwestern United States and Baja California; Geomyidae (especially Thomomys) and Heteromyidae (especially Dipodomys); field notes; specimens recorded in a catalogue arranged numerically; includes specimens formerly in private collections of S. G. Jewett and L. M. Huey; collection used primarily in research; person in charge is Joseph R. Jehl, Jr.; reported by Suzanne I. Bond, Research Assistant.

59. San Diego State University (SDSU), Department of Zoology, San Diego, 92115. $1462(+37)$; general representation, especially from the southwestern United States and Australia; including 260 skeletons and 75 zoo specimens of known age; specimens recorded in a catalogue arranged numerically; including bats formerly in Andrew C. Olsen, Jr., collection; collection used primarily in teaching; reported by Jason A. Lillegraven, Assistant Professor.

60. San Francisco State University (SFSU), Vertebrate Museum, San Francisco, 94132. $1900(+125)$; California, Arizona, and New York; Sciuridae; special files, including 300 $2 \times 2$ slides; specimens recorded in a catalogue arranged numerically; collection used primarily in teaching; reported by Joseph G. Hall, Curator of Mammals.

61. Santa Barbara Museum of Natural History (SBMNH), 2559 Puesta Del Sol Road, Santa Barbara, 93105. $981(+5)$; southern California; Rodentia; collection used primarily in teaching; reported by Waldo G. Abbott, Curator of Ornithology and Mammalogy.

62. United States Forest Service, San Joaquin Experimental Range (SJER), Coarsegold, 93614. $260(+100)$; lower foothills of western slope of Sierra Nevada; Rodentia; collection used primarily in public service and secondarily in research; reported by Don A. Duncan, Range Scientist. 
63. University of California, Berkeley, Department of Zoology (UCBDZ), Berkeley, 94720. 1025; a synoptic teaching collection from the San Francisco Bay region; specimens recorded in a catalogue arranged numerically; collection used entirely in teaching; reported by James L. Patton, Assistant Curator of Mammals and Assistant Professor of Zoology.

64. University of California, Berkeley, Museum of Vertebrate Zoology (MVZ), Berkeley, 94720. 144,000 $(+2500)$, not counting 500 specimens maintained separately for dissection; 330 holotypes; western United States, northwestern Mexico, Peru, and Australasia; 110 of the 120 extant families of mammals represented; including 13,500 specimens fixed in formalin and preserved in alcohol, 14,000 skeletons, 3000 karyotypes, 1000 electrophoretograms, 3000 specimens of known age, 500 domestic animals, 5000 bacula and/or glans, and 600 frozen carcasses; field notes; special files, including 2600 photographs, 500 photomicrographs, and 319 lantern slides; specimens recorded in catalogues arranged numerically, by systematic groups, by collectors, and both sequentially and systematically for anatomical materials; including specimens from El Salvador previously cited as being in Donald R. Dickey-California Institute of Technology Collection, and also including the O. P. Silliman Collection and the F. B. Sumner Collection (the latter formerly at Scripps Institution ); collection used primarily in research; persons in charge are William Z. Lidicker, Jr., and James L. Patton; reported by James L. Patton, Assistant Curator of Mammals.

65. University of California, Davis, Department of Anatomy (DAUCD), School of Veterinary Medicine, Davis, 95616. 600 skeletons of domestic animals (400 representing breeds of domestic beef cattle and 200 of purebred dogs, most with autopsy reports); collection used primarily in research; reported by Logan M. Julian, Professor of Anatomy.

66. University of California, Davis, Museum of Wildlife and Fisheries Biology (WFBM), Davis, 95616. $2000(+1000)$; Pacific and southwestern regions of the United States; Rodentia, Carnivora, and Artiodactyla; including 100 specimens in alcohol, 25 specimens in buffered formalin, 100 skeletons, 50 injected anatomical preps, 50 electrophoretograms, 150 specimens of known age, and 200 bacula and/or glans; field notes; special files, including 1500 photographs of specimens, 2000 photographs of habitats, 100 tape recordings, and 1500 feet of motion picture film; specimens recorded in catalogues arranged numerically, by systematic groups, by geographic areas, and by principal contributors; segregated teaching collection ( 500 specimens); collection used primarily in teaching; reported by Ronald E. Cole, Curator.

67. University of California, Davis, Museum of Zoology (UDAV), Davis, 95616. 1334 ( +40); California, Malaya, and Panama Canal Zone; Rodentia, Insectivora, Mustelidae, Lagomorpha, and Chiroptera; including 100 bacula and/or glans; specimens recorded in catalogues arranged numerically and by systematic groups; collection used primarily in teaching; person in charge is Robert L. Rudd; reported by Sean J. Barry, Student Curator.

68. University of California, Los Angeles (UCLA), UCLA-Dickey Collection of Birds and Mammals, Los Angeles, 90024. 18,460 $(+200)$; 48 holotypes; southwestern United States, Mexico, and Nicaragua; Rodentia; including 150 specimens in alcohol and 2500 skeletons; field notes; specimens recorded in catalogues arranged numerically and by systematic groups; including collection formerly at the California Institute of Technology (Donald R. Dickey Collection) and the formerly private collections of A. B. Howell, Loye H. Miller, and Raymond B. Cowles; segregated teaching collection; collection used primarily in research and secondarily in teaching; reported by James G. Miller, Senior Museum Scientist.

69. Yosemite National Park (YNPC), Box 577, Yosemite National Park, 95389. 990; synoptic local representation; field notes; collection used primarily in teaching and exhibition; reported by Jack Gyer, Curator.

\section{Colorado}

70. Adams State College (ADSC), Department of Biology, Alamosa, 81101. 392; local representation of small mammals (especially Rodentia); collection used primarily in teaching; reported by Veryl F. Keen, Chairman. 
71. Colorado State University (CSU), Department of Zoology and Entomology, Fort Collins, 80521. 550; north-central Colorado; Rodentia; reported in 1961 to include some specimens formerly in E. R. Warren Collection; segregated teaching collection (100 specimens); collection used almost exclusively in teaching; reported by Bruce A. Wunder, Assistant Professor.

72. Fort Lewis College (FLC), Durango, 81301. 200; local representation; collection used primarily in teaching; reported by A. W. Spencer.

73. Rocky Mountain Biological Laboratory (RMBL), Crested Butte, 81224. 400; local Microtinae; collection used about equally in research and teaching; reported by Richard E. Richards, Associate Director (address: Biology Department, Western State College, Gunnison, 81230).

74. Rocky Mountain National Park (RMNP), Estes Park, 80517. $550(+2)$; locally collected Ochotona, Marmota, Spermophilus, Eutamias, Peromyscus, Cleithrionomys, Zapus, and Mustela; collection used primarily in exhibition and interpretation; person in charge is Dwight L. Hamilton, Chief Park Naturalist; reported by John R. Douglas, Assistant Chief Park Naturalist.

75. University of Colorado Museum (UCM), Boulder, 80302. 14,100 (+2000); 1 holotype; Colorado, Arizona, Utah, and Alaska; Rodentia, Lagomorpha, Insectivora, and Chiroptera; including specimens in alcohol and in buffered formalin, skeletons, and mounted specimens; some field notes (including those for E. R. Warren Collection); special files, including photographs in E. R. Warren archives; specimens recorded in catalogues arranged numerically and by systematic groups; includes formerly private collections of Edward Royal Warren (WC) and Donald A. Spencer; segregated teaching collection; collection used primarily in research; persons in charge are Shi-kuei Wu (Curator of Zoology), William H. Burt (Associate Curator of Zoology), and David M. Armstrong (Associate Curator of Zoology); reported by D. M. Armstrong.

76. U. S. Bureau of Sport Fisheries and Wildlife, Denver Collection of the Bird and Mammal Laboratories (DCBML), Bldg. 45, Federal Center, Denver, 80225. 1300 $(+300)$; Rocky Mountain region; Rodentia; including 600 skeletons and 800 hair slides; field notes; special files, including a stomach content card file; specimens recorded in a catalogue arranged numerically; collection previously cited as the Denver Food Habits Laboratory or the Denver Wildlife Research Center of the Bureau of Sport Fisheries and Wildlife; collection used entirely in research, and is intended to serve as a repository for new growth of the Bird and Mammal Laboratories, National Museum of Natural History, Washington, D. C.; reported by Robert B. Finley, Jr., Zoologist.

77. Western State College (WSC), Gunnison, 81230. $350(+100)$; local Microtinae; collection used primarily in teaching; reported by Richard E. Richards, Assistant Professor of Biology.

\section{Connecticut}

78. University of Connecticut, Museum of Natural History (UCONN), Storrs, 06268. 16,200 ( +200); New England and Paraguay; broad representation; field notes; special files, including card file for mammals from New England in other collections; specimens recorded in a catalogue arranged numerically; including Fred L. Osgood Collection and part of the C. F. Jackson Collection; collection used primarily in research and secondarily in teaching; person in charge is Ralph M. Wetzel, Professor of Biology; reported by Robert Dubos, Educational Assistant.

\section{Delaware}

79. Delaware Museum of Natural History (DMNH), P.O. Box 3937, Greenville, 19807. 5000; Philippines and synoptic representation from North America; Rodentia and Lagomorpha; including 150 specimens in alcohol; some field notes; specimens recorded in a catalogue arranged numerically; collection used (albeit inactive at present) primarily in research; reported by John P. Hubbard, Curator of New World Birds. 
80. University of Delaware (UDEL), Department of Entomology and Applied Ecology, Newark, 19711. $260(+100)$; Delmarva Peninsula and mid-Atlantic states; Rodentia; collection used primarily in teaching and as a depository for voucher specimens; reported by Richard W. Rust, Assistant Professor.

\section{District of Columbia}

81. National Museum of Natural History (USNM) and Bird and Mammal Laboratories, U. S. Bureau of Sport Fisheries and Wildlife (BS), Washington, 20560. 475,000 $(+5500) ; 3000$ holotypes; North America, Africa, South America, Central America, and southeastern Asia; Rodentia, Chiroptera, Carnivora, Cetacea, Artiodactyla, and Primates; including 50,000 specimens in alcohol, a few specimens in buffered formalin, 5000 skeletons, a few injected anatomical preps, 100 microscopic preparations, 1500 mounted specimens, 400 specimens of known age, 1000 domestic animals, 2000 bacula and/or glans, cleared and alazarin-stained specimens, and frozen tissues; some field notes; special files, including 5000 photographs of specimens, a few photographs of habitats, a few color transparencies, $2002 \times 2$ slides, 1000 feet of motion picture film, and 200 x-ray photographs; specimens recorded in catalogues arranged numerically, by systematic groups, by geographic areas, and by collectors; including the C. Hart Merriam Collection and possibly others; segregated teaching collection (150 specimens); collection used primarily in research; persons in charge are Richard W. Thorington, Jr. (USNM), and Don E. Wilson (BS); reported by Robert D. Fisher, Museum Specialist for the Mammal Section, Bird and Mammal Laboratories.

\section{Florida}

82. Archbold Biological Station (ABS) of the American Museum of Natural History, Rt. 2, Box 380, Lake Placid, 33852. $300(+50)$; south-central peninsular Florida; Rodentia and Chiroptera; collection used primarily for reference by resident and visiting researchers; reported by James N. Layne, Director of Research for the Archbold Biological Station and Curator of Mammals of the American Museum of Natural History.

83. Florida State University (FSU), Department of Biological Sciences, Tallahassee, 32306. $630(+10)$; local representation; segregated teaching collection (30 specimens); collection used primarily in teaching; reported by Henry M. Stevenson, Associate Professor of Zoology.

84. Albert Schwartz Collection (AS); 6000; southeastern North America, the Antilles, and western North America; Chiroptera, Rodentia, and Carnivora; including 400 specimens in alcohol; specimens recorded in a catalogue arranged numerically; collection used primarily in teaching and secondarily in research; reported by owner (address: Department of Biology, Miami-Dade Community College, Miami, 33167).

85. Tall Timbers Research Station (TTRS), Rt. \#1, Box 160, Tallahassee, 32303. $704(+25)$; local representation; Chiroptera and Rodentia; field notes; collection used about equally in research, reference, and documentation; reported by W. Wilson Baker, Research Biologist.

86. University of Florida, The Florida State Museum (FSM), Gainesville, 32611. 15,598 (+300); 5 holotypes; Florida, Caribbean region, and southern Great Plains; Rodentia, Chiroptera, and Edentata; including 2000 specimens in alcohol, 4000 skeletons, 100 specimens of known age, and 100 domestic animals; specimens recorded in a catalogue arranged numerically; including formerly private collections of Joseph C. Moore, James N. Layne, William L. Jennings, H. B. Sherman, and W. W. Bowen; collection used primarily in research; reported by Stephen R. Humphrey, Assistant Curator of Mammalogy.

87. University of South Florida (USF), Biology Department, Tampa, 33620. 8000; western and southeastern United States; Rodentia, Insectivora, and Chiroptera; including 200 skeletons; some field notes; segregated teaching collection (200 specimens); reported by Larry N. Brown. 


\section{Georgia}

88. University of Georgia, Museum of Vertebrate Zoology (MVZUG), Athens, 30602. $2952(+50)$; Georgia and the coastal plain of South Carolina; Microtinae, Cricetinae, and Microchiroptera; specimens recorded in a catalogue arranged numerically and by systematic groups; segregated teaching collection (20 specimens); collection used primarily in teaching and for deposition of voucher specimens; reported by Robert J. Hamilton, Museum Curator.

\section{Hawaii}

89. Bernice P. Bishop Museum (BBM), Box 6037, Honolulu, 96818. 12,000 (+100); 6 holotypes; New Guinea and the Solomon Islands; Marsupialia, Chiroptera, and Muridae; including 800 specimens in alcohol, 400 skeletons, and 200 mounted specimens; field notes; specimens recorded in a catalogue arranged numerically; including formerly private collection of Watson T. Yoshimoto; collection used primarily in research; reported by Alan C. Ziegler, Vertebrate Zoologist.

\section{Idaho}

90. Idaho State University (IDAHO), Department of Biology, Pocatello, 83201. 700 $(+200)$; southeastern Idaho; Eutamias, Peromyscus, Microtus, and Thomomys; segregated teaching collection ( 50 specimens); collection was used primarily in teaching but its future is uncertain because of discontinuation of the institutional museum program; reported by Edson Fichter, Professor of Zoology.

\section{Illinois}

91. Field Museum of Natural History (FMNH), Chicago, 60605. 110,000 (+4000); 484 holotypes; Neotropical Region (35 percent of collection), Palearctic (17 percent), Nearctic (17 percent), Oriental (15 percent), Ethiopian (14 percent), Australian (2 percent); Rodentia, Chiroptera, Lagomorpha, Dermoptera, Hyracoidea, Carnivora, Insectivora, and Primates (in decreasing order of completeness); including 19,600 specimens in alcohol, 3000 skeletons, 900 injected anatomical preps, 500 microscopic preparations, 880 mounted specimens, 800 bacula and/or glans, and 138 auditory ossicles; field notes; specimens recorded in catalogues arranged numerically and by systematic groups; including collection formerly at Northwestern University; collection used primarily in research; reported by Luis de la Torre, Curator of Mammals.

92. Illinois Natural History Survey (INHS), Urbana, 61801. 600; Illinois; Chiroptera; used primarily as a reference collection in connection with an identification service provided by the Survey; reported by Philip W. Smith, Head of Section of Faunistic Surveys and Insect Identification.

93. Illinois State Museum (ISM), Springfield, 62706. $1300(+100)$; central Illinois; Sciuridae and Cricetidae; including 400 skeletons; specimens recorded in catalogues arranged numerically and by systematic groups; presumably containing the J. R. Paul Collection; collection used primarily in research and secondarily in exhibition; reported by John R. Paul, Curator of Zoology.

94. Illinois State University (ILLSU), Department of Biological Sciences, Normal, 61761. 1096; Mlinois; Rodentia; including 300 skeletons; specimens recorded in a catalogue arranged numerically; collection used primarily in teaching; reported by Dale E. Birkenholz, Professor of Biological Sciences.

95. Southern Illinois University-Carbondale (SIUC), Department of Zoology, Carbondale, 62901. $2777(+100)$; southern Illinois; Rodentia, Chiroptera, and Carnivora; including 1500 skeletons and a collection of calcanea (of rodents and carnivores); specimens recorded in catalogues arranged numerically and by systematic groups; collection used primarily in teaching; reported by Howard J. Stains, Professor of Zoology. 
96. University of Illinois, Museum of Natural History (UIMNH), Urbana, 61801. 48,701 ( +450 ); 15 holotypes; Arizona, Texas, New Mexico, northern Mexico, Illinois, Ohio, Tennessee, Philippine Islands; Cricetidae, Heteromyidae, Geomyidae, Vespertilionidae, Sylvilagus, southwestern Odocoileus, and Blarina; including 1000 specimens in alcohol, 1200 skeletons, 30 injected anatomical preps, 400 mounted specimens, 100 specimens of known age, 500 bacula and/or glans; field notes; special files, including 50 photographs of specimens, 150 photographs of habitats, 80 color transparencies, and 800 feet of motion picture film; specimens recorded in catalogues arranged numerically and by systematic groups; includes formerly private collections of W. W. Goodpaster, L. A. Adams, and Edward H. Taylor; segregated teaching collection (1000 specimens); collection used primarily in research; reported by Donald F. Hoffmeister, Director.

97. Western Illinois University (WIU), Department of Biological Sciences, Macomb, 61455. 1400; Illinois; Rodentia; including 100 specimens in alcohol; field notes; collection used primarily in teaching; reported by John E. Warnock, Professor of Biology.

\section{Indiana}

98. Earlham College, Joseph Moore Museum (JMM), Richmond, 47374. $3400(+120)$; Indiana; Vespertilionidae; including specimens in alcohol, skeletons, and specimens of known age; specimens recorded in catalogues arranged numerically and by systematic groups; segregated teaching collection; collection used primarily in teaching; reported by James B. Cope, Director.

99. Indiana State University (ISU), Department of Life Sciences, Terre Haute, 47800. 2400 , not including special preparations $(+1500)$; Indiana and New York; Rodentia, Insectivora, and Chiroptera; including 100 specimens in alcohol and 800 skeletons; field notes; special files include a McBee card for each specimen; specimens recorded in a catalogue arranged numerically; presumably including previously cited John $\mathrm{O}$. Whitaker, Jr., Collection; collection used about equally in teaching and research; reported by John O. Whitaker, Jr., Professor of Life Sciences.

100. Purdue University, Wildlife Laboratory Collection (PUWL), and R. E. Mumford Collection (REMC), Department of Forestry and Conservation, Lafayette, 47907. 3100 $(+2500)$; Indiana, Kenya, and Brazil; Chiroptera and Rodentia; field notes; some specimens recorded in a catalogue arranged numerically; collection used about equally in teaching and research; reported by R. E. Mumford, Professor of Wildlife Management.

\section{Iowa}

101. Central College (CUI), Department of Biology, Pella, 50219. 200 $(+50)$; Iowa and Yucatan; field notes; collection used primarily in teaching; reported by John B. Bowles, Associate Professor of Biology.

102. Coe College (CCI), Biology Department, Cedar Rapids, 52402. $350(+30)$; eastern Iowa; Rodentia and Mustelidae; some field notes; collection used primarily in teaching; reported by Karl E. Goellner, Professor of Biology.

103. Davenport Museum (DM), 1717 W. 12th, Davenport, 52804. $535(+7)$; central North America and Africa; Rodentia and Carnivora; including 62 mounted specimens; collection used primarily in exhibition; reported by Janice A. Hall, Curator of Natural History.

104. Iowa State University, Museum of Zoology (ISUMZ), Ames, 50010. $2000(+25$ ); Iowa; Rodentia and Carnivora; including 100 mounted specimens; field notes; specimens recorded in catalogues arranged numerically and by geographic areas; presumably including formerly private collection of Thomas Scott; collection used primarily in teaching and public service; reported by Michael K. Peterson, Assistant Professor.

105. Luther College, Sherman Hoslett Memorial Museum of Natural History (SHMC), Decorah 52101. $1200(+100)$; northeastern Iowa; Cricetinae, Microtinae, and Soricidae; 
including skeletons, mounted specimens, and domestic animals; some field notes; specimens recorded in catalogues arranged numerically, by systematic groups, by geographic areas, and by collectors; including the William Blagen Collection and part of the Sherman Hoslett Collection; segregated teaching collection (100 specimens); collection used primarily in teaching; reported by David Roslien, Associate Professor of Biology.

106. University of Iowa (IOWA), Museum of Natural History, Iowa City, 52240. 2000; Iowa, Mackenzie River region of Canada, and Australia; Rodentia, Marsupialia, and Carnivora, including 200 mounted specimens; some field notes; specimens recorded in catalogues arranged numerically and by systematic groups; collection used primarily in exhibition and teaching; reported by George D. Schrimper, Curator.

107. University of Northern Iowa (UNI), Department of Biology, Cedar Falls, 50613. 340; Kentucky and Indiana; Chiroptera; field notes; presumably also includes previously reported Nixon Wilson Collection; collection used primarily in research; reported by Nixon Wilson, Associate Professor of Biology.

\section{Kansas}

108. Fort Hays Kansas State College, Museum of the High Plains (MHP), Hays, 67601. 12,000 $(+1000)$; Kansas, New Mexico, Chiapas, and northwestern United States; Vespertilionidae, Sciuridae, Heteromyidae, and Cricetidae; including 200 specimens in alcohol, 300 skeletons, and 120 homogenized and dried specimens (for studies of body composition and lipid cycling); field notes; special files, including 10,000 photographs of habitats, numerous $2 \times 2$ slides and lantern slides, and an ecological data file; specimens recorded in catalogues arranged numerically and by systematic groups; segregated teaching collection (100 specimens); collection used primarily in research and secondarily in teaching; reported by Jerry R. Choate, Director and Curator of Mammals.

109. Fort Hays Kansas State College, Sternberg Memorial Museum (FHSM), Hays, 67601. 200; Artiodactyla; including 111 mounted specimens; collection used primarily in exhibition and secondarily in teaching; person in charge is Richard J. Zakrzewski, Director; reported by Dan Zehr, Graduate Assistant.

110. Friends University, Fellow-Reeve Museum (FRM), 2100 University, Wichita, 67213. 130; Alaska and Africa; collection used primarily in teaching and exhibition; reported by Ernest R. Parson, Curator.

111. Kansas State College of Pittsburg (KSCP), Department of Biology, Pittsburg, 66762. 1024; southeastern Kansas and southwestern Missouri; Chiroptera; field notes; specimens recorded in catalogues arranged numerically and by geographic areas; collection used primarily in teaching; reported by Horace A. Hays, Professor of Biology.

112. Kansas State University (KSU), Division of Biology, Manhattan, 66506. 800 $(+200)$; Kansas; Rodentia, Lagomorpha, and Carnivora; some field notes; collection used primarily in teaching; reported by Otto Tiemeier, Professor of Biology.

113. Southwestern College (SCK), Department of Biology, Winfield, 67156, 1160 $(+50)$; Kansas and Arizona; Rodentia; field notes; specimens recorded in a catalogue arranged by systematic groups; segregated teaching collection ( 150 specimens); collection used primarily in teaching; reported by Max C. Thompson, Assistant Professor of Biology.

114. St. Francis Community Junior-Senior High School (SFHS), St. Francis, 67756. 800; northwestern Kansas; Rodentia; field notes; collection used entirely in teaching; reported by Jack R. Walker, Biology Instructor.

115. University of Kansas, Museum of Natural History (KU), Lawrence, 66045. 132,000 ( +4000); 118 holotypes; western United States and Central America; Insectivora, Chiroptera, and Rodentia; including specimens in alcohol and in buffered formalin, skeletons, karyotypic and microscopic preparations, mounted specimens, electrophoretograms, specimens of known age, domestic animals, and bacula and/or glans; field notes; special files, including tape recordings, lantern slides, and motion pictures; specimens recorded in catalogues arranged numerically and by systematic groups; including formerly private 
collections of W. Cutter, W. W. Dalquest, R. Ellis, A. M. Mickey, and M. D. Tuttle, plus the collection formerly at Collegio San José, Cumaná, Venezuela; segregated teaching collection; collection used primarily in research; reported by Robert S. Hoffmann, Curator of Mammals.

116. Wichita State University (WSBC), Biology Department, Wichita, 67208. 200; local Rodentia; field notes; collection used primarily in teaching; reported by D. A. Distler, Associate Professor of Biology.

\section{Kentucky}

117. Wayne H. Davis Collection (WHDC); 300; West Virginia; Parascalops breweri, Sorex fumeus, and representatives of all species of bats in the United States except Euderma maculatum; collection used primarily in teaching and secondarily in research; reported by owner (address: School of Biological Sciences, University of Kentucky, Lexington, 40506).

118. Eastern Kentucky University (EKU), Department of Biological Sciences, Richmond, 40475. $500(+100)$; central and eastern Kentucky and southern Indiana; Insectivora; including 500 skulls of Marmota monax; collection used primarily in teaching; reported by M. Pete Thompson, Associate Professor of Biology.

119. Georgetown College (GCK), Biology Department, Georgetown, 40324. 160; southeastern Indiana and central Kentucky; Chiroptera and Rodentia; collection used primarily in teaching; reported by Dwight M. Lindsay, Professor of Biology.

120. University of Kentucky (UKEN), School of Biology, Lexington, 40506. 5250; Kentucky; Microtus; field notes; specimens recorded in a catalogue arranged numerically; collection used about equally in research and teaching; reported by Roger W. Barbour, Professor of Zoology.

\section{Louisiana}

121. Centenary College (CVC), Department of Biology, Shreveport, 71104. $400(+50)$; Louisiana, southern Illinois, Indiana, and Costa Rica; Rodentia and Marsupialia; field notes; collection used entirely in teaching (specimens with research value are transferred to Louisiana State University); reported by A. B. McPherson, Assistant Professor of Biology.

122. Louisiana State University, Museum of Zoology (LSUMZ), Baton Rouge, 70803. $18,518(+500) ; 22$ holotypes; southeastern United States, Mexico (San Luis Potosi and Tabasco), Costa Rica, Peru, and the Bahamas; including 800 specimens in alcohol, 500 skeletons, and 100 bacula and/or glans; field notes; special files include numerous photographs; specimens recorded in catalogues arranged numerically and by systematic groups; including the Ganier Tennessee collection; segregated teaching collection (100 specimens); collection used primarily in research; reported by George H. Lowery, Jr., Director.

123. Louisiana Tech University (LTU), Department of Zoology, Ruston, 71270. 1500 $(+500)$; Louisiana; Cricetidae, Sciuridae, and Leporidae; specimens recorded in a catalogue arranged numerically; segregated teaching collection (100 specimens); collection used primarily in teaching and secondarily in research; reported by John W. Goertz, Professor of Zoology.

124. Northeast Louisiana University (NELU), Department of Biology, Monroe, 71201. 1100; northeastern Louisiana; Rodentia; field notes; specimens recorded in a catalogue arranged numerically; collection used primarily in teaching; reported by David T. Kee, Associate Professor of Biology.

125. Northwestern State University of Louisiana (NSUL), Department of Biology, Natchitoches, 71457. $1500(+240)$; Louisiana; Rodentia and Carnivora; including 100 skeletons; some specimens recorded in a catalogue arranged numerically; collection used primarily in teaching; reported by Dick T. Stalling, Assistant Professor of Biology.

126. Southeastern Louisiana University (SELU), Department of Biology, Hammond, 70401. $700(+223)$; local representation; field notes; collection used about equally in teaching and research; reported by J. Larry Crain, Associate Professor of Biology. 
127. Tulane University ( $\mathrm{TU}$ ), Systematic and Environmental Biology Laboratory, Herbert Center, Riverside Research Laboratories, Route 1, Box 46-B, Belle Chasse, 70037. $4282(+1004)$; southern and southwestern United States, Rio Muni, Colombia, and Thailand; Vespertilionidae, Sciuridae, Geomyidae, Heteromyidae, and Cricetidae; including 843 skeletons (plus 194 not yet catalogued); field notes; specimens recorded in a catalogue arranged numerically; collection used primarily in research; reported by Royal D. Suttkus, Professor of Biology.

128. University of Southwestern Louisiana, (USLBM), Department of Biology, Box 545, Lafayette, 70501. $3500(+300)$; southern Louisiana and Colorado; Cricetidae; field notes; specimens recorded in a catalogue arranged numerically and in a systematic card file (for specimens from Louisiana only); collection used primarily in teaching; reported by Marshall B. Eyster, Professor of Biology.

\section{Maine}

129. University of Maine, Department of Zoology (MAINE), Orono, 04473. 855 $(+300)$; Maine; Peromyscus; including collection (185 specimens) of Portland Society of Natural History-Maine Audubon Society Museum on a permanent loan basis; collection used primarily in teaching; reported by Albert A. Barden, Jr., Professor of Zoology.

130. University of Maine, School of Forest Resources (MSFR), Orono, 04473. 218; New England; Sciuridae; collection used primarily in teaching; reported by Voit B. Richens, Assistant Leader of Maine Cooperative Wildlife Research Unit.

\section{Massachusetts}

131. Boston University (BU), Biology Department, Boston, 02215. $400(+50)$; collection used entirely in teaching; reported by Thomas H. Kunz, Assistant Professor.

132. Harvard University, Museum of Comparative Zoology (MCZ), Oxford Street, Cambridge, 02138. 69,000 (+1000); 274 holotypes; United States, Canada, northern and Gulf coastal Mexico, Panama, Honduras, Cuba, Argentina, Brasil, Colombia, Ecuador, Peru, China, Korea, Borneo, French Indochina, India, Java, New Guinea, Philippines, Siam, Sumatra, Australia, Cameroons, eastern Africa, Liberia, Madagascar, southern and southwestern Africa, and Sudan; broad representation, including Cetacea; including specimens in alcohol, skeletons, mounted specimens, domestic animals, and bacula and/or glans; field notes; specimens recorded in a catalogue arranged numerically and, in part, by systematic groups and geographic areas; includes the previously cited O. Bangs Collection (New England Museum of Natural History) and the private collections of C. F. Batchelder, Ralph S. Palmer, and Manton Copeland; segregated teaching collection; collection used primarily in research; reported by Barbara Lawrence, Curator of the Mammal Department.

133. David A. Lovejoy Collection (DALC); 300; White Mountains (New Hampshire) and western Massachusetts; Cricetidae; including 400 fleas removed from specimens; field notes; collection used about equally in teaching and research; reported by owner (address: Department of Biology, Westfield State College, Westfield, 01085).

134. Peabody Museum (PMS), Salem, 01970. 218; local representation; field notes; collection used primarily in teaching and exhibition; reported by Sarah P. Ingalls, Curator of Natural History.

135. Springfield Science Museum (SSM), 236 State Street, Springfield, 01103. 240 mounted specimens; eastern North America; collection used primarily in exhibition and teaching; reported by Earl H. Reed, Senior Curator.

136. University of Massachusetts, Department of Forestry and Wildlife Management (DFWM), Amherst, 01002. 440; western Massachusetts; Cricetidae, Soricidae, Leporidae, and Vespertilionidae; collection used primarily in teaching; person in charge is Frederick Greeley; reported by Joseph S. Larson, Associate Professor of Wildlife Biology. 
137. University of Massachusetts (UMASS), Museum of Zoology, Amherst, 01002. $2250(+300)$; New England, western United States; Rodentia and Insectivora; including 300 specimens in alcohol; specimens recorded in catalogues arranged numerically, by systematic groups, and by geographic areas; segregated teaching collection (500 specimens); collection used primarily in research and secondarily in graduate teaching; reported by David Klingener, Associate Professor and Associate Chairman of the Department of Zoology.

138. Westfield State College (WSCM), Department of Biology, Westfield, 01085. 250 $(+20)$; western Massachusetts; collection used primarily in teaching; reported by David A. Lovejoy, Assistant Professor of Biology.

\section{Michigan}

139. Central Michigan University, Center for Cultural and Natural History (CCNH), Mt. Pleasant, 48859. $1629(+60)$; Great Lakes region; Sciuridae and Peromyscus; specimens recorded in catalogues arranged numerically, by systematic groups, and by collectors; collection used primarily in teaching; person in charge is Lynn Fauver; reported by Richard J. Brown, Curator of Zoology.

140. Cranbrook Institute of Science (CIS), P.O. Box 807, Bloomfield Hills, 48013. $500(+100)$; Arizona and Michigan; Sciuridae, Peromyscus, Microtus, Blarina, Mustelidae, and Felidae; segregated teaching collection; collection used primarily in teaching, exhibition and reference; reported by Philip T. Clampitt, Zoologist.

141. Grand Rapids Public Museum (GRPM), 54 Jefferson Ave. S. E., Grand Rapids, 49502. 310; western Michigan; field notes; collections used primarily in exhibition; reported by W. D. Frankforter, Director.

142. Hope College (HCMZ), Department of Biology, Holland, 49423. $300(+20)$; southwestern Michigan; including specimens formerly in collection at Swan Creek Wildlife Experiment Station; collection used primarily in teaching; reported by Eldon D. Greij, Associate Professor of Biology.

143. Lake Superior State College (LSSC), Sault Ste. Marie, 49783. 250; Michigan; Rodentia and Carnivora; collection used entirely in teaching; reported by R. E. Reilly, Associate Professor.

144. Michigan State University (MSU), The Museum, East Lansing, 48823. 22,074 $(+200)$; Michigan, central Chile, central Argentina, northwestern Mexico, and western Ecuador; Rodentia, Ursidae, Felis pardalis, Lynx, Tayassu, Lutra, and Chiroptera; including 1500 specimens in alcohol, 4000 skeletons, 100 mounted specimens, 200 electrophoretograms, 1000 specimens of known age, 40 domestic animals, 3000 bacula and/or glans, and a live animal colony consisting of approximately 500 rodents and small carnivores from Michigan, Mexico, Panama, Argentina, southwestern Africa, and elsewhere; field notes; special files, including photographs, color transparencies, photomicrographs, $2 \times 2$ slides, motion pictures, and donor files; specimens recorded in a catalogue arranged numerically (live mammals and their pedigrees recorded by means of special data sheets); including collection of Rose Lake Wildlife Research Center (on permanent loan); segregated teaching collection ( 300 specimens); collection used primarily in research and secondarily in teaching; person in charge is Rollin H. Baker, Director (Richard Hill is Curator in charge of Living Materials); reported by Larry Bowdre, Assistant Curator of Mammals.

145. Michigan Technological University (MTU), Department of Biological Sciences, Houghton, 49931. 150; Lake Superior region; Sciuridae only; presumably containing part of the collection formerly at the Great Smoky Mountains National Park; collection used primarily in research and secondarily in teaching; reported by Kenneth R. Kramm, Assistant Professor.

146. Frederick H. Test Collection (FHTC); 330; Michigan; Cricetidae and Soricidae; field notes; previously cited as being at The University of Michigan Biological Station, Pellston; reported by owner (address: Department of Zoology, The University of Michigan, Ann Arbor, 48104). 
147. University of Michigan, Department of Zoology (UMDZ), Ann Arbor, 48104. $550(+150)$; Michigan; Rodentia; collection used entirely in teaching; reported by Frederick H. Test, Professor of Zoology.

148. University of Michigan, Museum of Zoology (UMMZ), Ann Arbor, 48104. $111,800(+500)$; 122 holotypes; Michigan, southwestern United States, and Middle America; New World Rodentia, North American Carnivora, and New World Chiroptera; including 12,000 specimens fixed in 10 percent buffered formalin and stored in 70 percent buffered alcohol, 700 specimens in buffered formalin, 7000 skeletons, 12 injected anatomical preps, 100 karyotypic preparations, 250 microscopic preparations, 55 mounted specimens, 2000 specimens of known age, 100 domestic animals, 6800 bacula and/or glans, and various kinds of mammalian "signs" (for example, nests, scats, gnawings, stomach contents); field notes; special files, including photographs of specimens and habitats and $2 \times 2$ slides; specimens recorded in catalogues arranged numerically, by systematic groups, and by geographic areas; including collection formerly at the Laboratory of Vertebrate Biology of The University of Michigan as well as part of both the D. R. Dickey Collection and the collection of the Cleveland Museum of Natural History; segregated teaching collection (200 specimens); collection used primarily in research; person in charge is Emmet T. Hopper, Professor of Zoology; reported by Michael D. Carleton, Museum Technician.

149. University of Michigan-Flint (UMF), Biology Department, Flint, 48503. 1000; New York; Soricidae (especially Blarina); including 400 skeletons; field notes; specimens recorded in a catalogue arranged numerically; collection not presently being used; reported by Richard W. Dapson, Associate Professor of Biology.

150. Wayne State University, Museum of Natural History (WSMNH), Detroit, 48202. 1252 ( +100$)$; Michigan; Rodentia; including 350 skeletons; special files, including 3 motion pictures; specimens recorded in catalogues arranged numerically, by systematic groups, and by collectors; segregated teaching collection ( 56 specimens); collection used primarily in teaching; reported by William L. Thompson, Director and Professor of Biology.

\section{Minnesota}

151. Bemidji State College (BSCVC), Department of Biology, Bemidji, 56601. 1680 $(+15)$; Minnesota and upper Midwest; Soricidae, Sciuridae, Peromyscus, Microtus, Clethrionomys, and Zapus; field notes; specimens recorded in catalogues arranged numerically and by systematic groups; collection used primarily in teaching and exhibition; reported by Evan B. Hazard, Professor of Biology.

152. St. John's University (SJU), Department of Biology, Collegeville, 56321. 600; central Minnesota; Rodentia; collection used primarily in teaching; reported by Norman L. Ford, Chairman.

153. The Science Museum of Minnesota (SMM), 30 E. Tenth, St. Paul, 55101. 350 $(+75)$; Upper Midwest; Carnivora, Rodentia, and Artiodactyla; recent field notes; collection used primarily in documentation; reported by Dale A. Chelberg, Curator of Biology.

154. University of Minnesota, Department of Entomology, Fisheries, and Wildlife (DEFW), St. Paul, 55108. 800; Minnesota; collection used primarily in teaching (all specimens with sufficient data have been transferred to James Ford Bell Museum of Natural History, Minneapolis); reported by William H. Marshall, Professor of Wildlife Management.

155. University of Minnesota, James Ford Bell Museum of Natural History (MMNH), Minneapolis, 55455. 12,500 (+1000); Upper Midwest and Mexico; Rodentia, Chiroptera, and Carnivora; including 150 specimens in alcohol, 500 skeletons (some mounted), 150 mounted specimens, and 100 specimens of known age; field notes (since 1970); specimens recorded in catalogues arranged numerically and by systematic groups; including specimens previously cited as being in different collections, but the identity of those collections is not available; segregated teaching collection (200 specimens); collection used primarily in research; reported by Elmer C. Birney, Curator of Mammals. 
156. University of Minnesota-Duluth (UMD), Department of Biology, Duluth, 55812. $1000(+50)$; northeastern Minnesota and northwestern Wisconsin; Soricidae, Cricetidae, and Sciuridae; field notes; specimens are recorded in catalogues arranged numerically and by systematic groups; collections used primarily in teaching; reported by Hollie L. Collins, Associate Professor of Biology.

\section{Mississippi}

157. Mississippi Museum of Natural Science, The Fannye A. Cook Memorial (FACM) (a division of the Mississippi Game and Fish Commission), 111 N. Jefferson Street, Jackson, 39202. 6000; Mississippi; Soricidae, Talpidae, Sciuridae, and Cricetidae; including 300 specimens in formalin and 100 mounted specimens; some field notes; specimens recorded in catalogues arranged numerically, by systematic groups, and by geographic areas (counties in Mississippi); collection used primarily in research and secondarily in exhibition; reported by B. E. Gandy, Museum Director.

158. Mississippi State University (MISSU), Department of Zoology, Mississippi State, 39762. 500; north-central Mississippi; Cricetidae; collection used primarily in teaching and any specimens with research potential are deposited in the Mississippi Museum of Natural Science; reported by James L. Wolfe, Associate Professor of Zoology.

\section{Missouri}

159. Kyle R. Barbehenn Collection (KRBC); 4000; Guam and Saipan; Suncus murinus; including 2000 specimens in alcohol; field notes; specimens recorded in catalogues arranged numerically, by systematic groups, and by geographic areas; collection used primarily in research; reported by owner (address given was Box 1126, Washington University, St. Louis, 63130; according to Theodore H. Fleming, University of Missouri-St. Louis, Barbehenn has moved to Washington, D. C., to work for the EPA).

160. Central Missouri State University (CMSU), Biology Department, Warrensburg, 64093. 1190; Missouri; Cricetidae; field notes (since 1972); specimens recorded in a catalogue arranged numerically; collection used entirely in teaching; reported by Edwin J. Keppner, Assistant Professor of Biology.

161. Northwest Missouri State University (NWMSU), Department of Biology, Maryville, 64468. 2000; Missouri and western Texas; Chiroptera; including 150 specimens in formalin; field notes; specimens recorded in catalogues arranged numerically and by collectors; collection used primarily in teaching and secondarily in research; reported by David A. Easterla, Assistant Professor of Biology.

162. University of Missouri (MOU), Columbia, 65201. 3481 $(+100)$; Missouri and Manitoba; Chiroptera; including 1000 bacula and/or glans and 12 skeletons imbedded in plastic; field notes; specimens recorded in catalogues arranged numerically, by systematic groups, and by geographic areas; segregated teaching collection (500 specimens); collection used primarily in documentation and research; reported by William H. Elder, Professor of Fisheries and Wildlife.

\section{Montana}

163. David J. Fassler Collection (DJFC); 400; western Colorado, southwestern Montana, and south-central Kentucky; 100 species, especially Chiroptera and Rodentia; field notes; collection formerly used primarily in teaching; reported by owner (address: P.O. Box 31, Bozeman, 59715).

164. Glacier National Park (GNP), West Glacier, 59936. $195(+10)$; local Rodentia, Carnivora, and Artiodactyla; including 95 mounted specimens; reported in 1963 to include the Frank Liebig Collection; collection used primarily in interpretation; person in charge is Edwin L. Rothfuss, Chief Park Naturalist; reported by Roberta V. Seibel, Park Biologist. 
165. Montana State University, Department of Fish and Game, Wildlife Laboratory (MSUWL), Bozeman, 59715. 6100; western Montana; including 100 big game skeletons, 1000 skulls of Castor canadensis, and 5000 skulls of Mustela vison; field notes; collection used primarily in public service and research; reported by Kenneth R. Greer, Supervisor.

166. Bob Scriver Collection (BSC); 108; Montana; field notes; collection used primarily in exhibition; reported by owner (address: Box 172, Browning, 59417).

167. University of Montana (UM), Department of Zoology, Missoula, 59801. 9685 $(+350)$; Montana, USSR, British Columbia, western United States, and Africa; Carnivora (including 600 skulls of Martes americana and 200 of Taxidea taxus) and Artiodactyla (including 150 skulls of Ovis canadensis); including 240 specimens in alcohol, 200 specimens in buffered formalin, and 300 skeletons; field notes; specimens recorded in catalogues arranged numerically and by systematic groups; segregated teaching collection (100 specimens); collection used primarily in teaching and secondarily in research; reported by Philip L. Wright, Professor of Zoology and Wildlife Biology.

\section{Nebraska}

168. Fort Niobrara National Wildlife Refuge (FNNWR), Hidden Timber Route, Valentine, 69201. 100; local Rodentia and Canidae; collection used entirely in exhibition; person in charge is Robert M. Ellis, Refuge Manager; reported by John W. Koerner, Assistant Refuge Manager.

169. Hastings Museum (HM), Hastings, 68901. 500; Nebraska; Rodentia; most specimens mounted; few field notes; collection probably used primarily in exhibition and perhaps secondarily in research; person in charge is Burton Nelson, Director; reported by J. Knox Jones, Jr., (Texas Tech University) based on his recollections of the collection several years ago.

170. Kearney State College, Vertebrate Museum (VMKSC), Kearney, 68847. 1500 $(+2000)$; Nebraska; Chiroptera and Rodentia; including (counting uncatalogued materials) 1000 specimens in alcohol, 200 skeletons, 300 karyotypic preparations, and 500 microscopic preparations; field notes; special files, including $2002 \times 2$ slides and 100 x-ray photographs; specimens are recorded in a catalogue arranged numerically; segregated teaching collection (200 specimens); collection used primarily in research and secondarily in teaching; reported by John P. Farney, Assistant Professor and Curator of Mammals.

171. University of Nebraska, State Museum (UNSM), 14th and U Street, Lincoln, 68508. $9500(+200)$; Nebraska; including 500 skeletons and 300 mounted specimens; field notes; specimens recorded in catalogues arranged numerically and by systematic groups; segregated teaching collection ( 200 specimens); collection used about equally in research and teaching; reported by Harvey L. Gunderson, Associate Director and Professor of Zoology.

172. Ralph Velich Collection (RVC); 470; eastern Nebraska, Puerto Rico, and South and Central America; field notes; collection used primarily in exhibition; reported by owner (address: 5212 S. 23rd Street, Omaha).

\section{Nevada}

173. J. R. Alcorn Collection (JRAC); 1000; Nevada; Rodentia; field notes; specimens recorded in a catalogue arranged numerically; collection used primarily in research; reported by owner (address: 6495 Power Line Road, Fallon, 89406).

174. Charles L. Douglas Collection (CLDC); $300(+100)$; southwestern United States; Rodentia; including 200 skeletons; field notes; collection used primarily in research and secondarily in teaching; reported by owner (address: 4325 Fortune Avenue, Las Vegas, 89107).

175. Nevada State Museum (NEVSM); 600 N. Carson Street, Carson City, 89701. 918; Nevada; Rodentia; segregated teaching collection (100 specimens); collection used 
primarily in exhibition; person in charge is Peter J. Herlan, Curator of Biology; reported by Ann Pinzl, Assistant Curator of Biology.

176. University of Nevada, Las Vegas (UNLV), Department of Biological Sciences, Las Vegas, 89154; 11,000 $(+3000)$; southwestern United States and western Mexico; Heteromyidae, Sciuridae, Cricetidae, and Chiroptera; including 1000 specimens in alcohol, 500 specimens in buffered formalin, 100 skeletons, 100 specimens of known age, 100 domestic animals, and 100 bacula and/or glans; special files, including photographs, $2 \times 2$ slides, motion pictures, and $\mathrm{x}$-ray photographs; specimens recorded in a catalogue arranged numerically; segregated teaching collection (100 specimens); collection used primarily in research and secondarily in teaching; person in charge is W. Glen Bradley, Professor of Biological Sciences; reported by Kenneth S. Moor, Research Associate.

\section{New Hampshire}

177. Dartmouth College Museum (DCM), Hanover, 03755. 3500; northern New England; Rodentia; field notes; specimens recorded in a catalogue arranged numerically; collection used primarily in teaching; reported by Robert G. Chaffe, Director.

178. University of New Hampshire (UNHP), Department of Zoology, Durham, 03824. $500(+150)$; northern New England; Cricetinae and Microtinae; collection used primarily in teaching; reported by Edward N. Francq, Assistant Professor of Zoology.

\section{New Jersey}

179. Princeton University (PU), Museum of Natural History, Princeton, 08540. $700(+20)$; Australia and North America; Marsupialia; collection consists entirely of osteological material; including Ashley Montagu Anthropological Collection; collection used primarily in teaching and secondarily in research; person in charge is Donald Baird, Curator of Museum; reported by Charles L. Smart, Curator of Mammals.

\section{New Mexico}

180. Eastern New Mexico University (ENMU), Natural History Museum, Portales, 88130. $3200(+150)$; Llano Estacado and adjacent river valleys of New Mexico; Rodentia; including 150 specimens in alcohol; field notes; special files, including 100 photographs of habitats; specimens recorded in a catalogue arranged numerically; collection used primarily in research; reported by A. L. Gennaro, Curator.

181. New Mexico Environmental Improvement Agency (NMEIA), Insect and Rodent Control Section, P.O. Box 2348, Santa Fe, 87501. 160; New Mexico; Rodentia; field notes; collection used primarily for reference by workers in vector control; reported by Neil S. Weber, Environmental Program Manager.

182. New Mexico State University (NMSU), Department of Biology, Las Cruces, 88003. $4141(+1120)$; southern New Mexico; Thomomys; including 1500 karyotypic preparations and 800 bacula and/or glans; recent field notes; specimens recorded in a catalogue arranged numerically; segregated teaching collection (100 specimens); collection used primarily in research and secondarily in teaching; reported by Charles S. Thaeler, Jr., Associate Professor of Biology.

183. Seton Memorial Library and Museum (SETON), Philmont Scout Ranch and Explorer Base, Cimarron, 87714. $500(+400)$; Ontario and the northeastern United States; field notes; including specimens formerly in E. T. Seton Collection; primary goal of collection is research; reported by Eleanor Pratt, Director of Museums.

184. University of New Mexico, Museum of Southwestern Biology (MSB), Albuquerque, 87106. 35,000 ( +200$)$; 1 holotype; New Mexico, western United States, western Mexico, and Costa Rica; Chiroptera and Rodentia (especially Heteromyidae); including 3000 specimens in alcohol, 1000 skeletons, 500 karyotypic preparations, 500 microscopic preparations, 
8000 bacula and/or glans, and a fecal collection; field notes; specimens recorded in catalogues arranged numerically and by systematic groups; segregated teaching collection (100 specimens); collection used primarily in research; reported by James S. Findley, Professor and Curator of Mammals.

185. Western New Mexico University (WNMU), Department of Biology, Silver City, 88061. 2500 (+200); southwestern New Mexico and Kenya; Chiroptera and Rodentia; field notes; specimens recorded in a catalogue arranged numerically; segregated teaching collection; collection used primarily in teaching; reported by Bruce J. Hayward, Associate Professor of Biological Sciences.

\section{New York}

186. American Museum of Natural History (AMNH), Central Park West at 79th Street, New York, 10024. 240,000 $(+1000)$; 950 holotypes; 79,691 specimens from North America, 41,198 from South America, 29,010 from Eurasia, 28,639 from Africa, 12,698 from the Australian Region, and 7025 from Oceania (based only on catalogue numbers 1-190,000 and 200,000-210,000); 112 specimens of Monotremata, 4864 Marsupialia (not including Archbold Collection), 6516 Insectivora, 39 Dermoptera, 25,444 Chiroptera, 6050 Primates, 991 Edentata, 1755 Lagomorpha, 77 Pholidota, 59,636 Rodentia, 221 Cetacea, 8563 Carnivora, 29 Tubulidentata, 99 Proboscidea, 238 Hyracoidea, 51 Sirenia, 520 Perissodactyla, and 3789 Artiodactyla (based only on catalogue numbers $60,000-150,000,160,000$ 190,000 , and $200,000-220,000$ ); including 12 percent of collection in alcohol, a few specimens in buffered formalin, 15,000 skeletons, a few injected anatomical preps, 500 karyotypic preparations, a few microscopic preparations, 2500 mounted specimens, 500 specimens of known age, several hundred domestic animals (including numerous special preparations and models), several hundred bacula and/or glans, and life-sized models of cetaceans; field notes; specimens recorded in catalogues arranged numerically, by systematic groups, by geographic areas (Termatrex retrieval system), and by collectors; collection used primarily in research; reported by Sydney Anderson, Chairman and Curator.

187. Colgate University (COLU), Department of Biology, Hamilton, 13346. 390; Jamaica, and central New York; West Indian Chiroptera and local Soricidae, Vespertilionidae, and Rodentia; reported by R. E. Goodwin, Professor.

188. Cornell University ( $C U$ ), section of Ecology and Systematics, Langmuir Laboratory, Ithaca, 14850. 14,000 $(+400)$; eastern North America; Rodentia, Insectivora, and Chiroptera; including 200 specimens in alcohol, 500 skeletons, 300 bacula and/or glans, and 50 scats; some field notes; special files, including $15502 \times 2$ slides, specimens recorded in catalogues arranged numerically and by systematic groups; segregated teaching collection ( 700 specimens); collection used primarily in teaching; reported by Rollin G. Bauer, Curatorial Associate for Birds and Mammals.

189. D. C. Gordon Collection (DCGC); 218; northern New York; Sciuridae, Cricetidae, Zapodidae, and Vespertilionidae; field notes; collection used primarily in research, and has been willed to The University of Kansas Museum of Natural History; reported by owner (address: 1390 Marra Drive, Watertown, 13601).

190. Mohonk Museum (MM), New Palta, 12561. 150; local representation; field notes; collection used primarily in teaching and in "baseline study;" reported by Daniel Smiley.

191. New York State Museum and Science Service (NYSM), Albany, 12224. 5500 $(+200)$; New York; small mammals; including 100 specimens in alcohol, 500 skeletons, and 100 mounted specimens; field notes; specimens recorded in a catalogue arranged by systematic groups; including the Roy C. Latham Collection and 100 specimens from the D. C. Gordon Collection; collection used primarily in research; reported by Edgar M. Reilly, Jr., Senior Scientist for Zoology (Curator).

192. State University of New York, Oneonta (SUNYO), Biology Department, Oneonta, 13820. 2000; New York; specimens recorded in a catalogue arranged numerically; collection used primarily in teaching; reported by John G. New, Professor of Biology. 
193. State University of New York, Syracuse (SUNYS), College of Environmental Science and Forestry, Syracuse, 13210. 2200; central New York; Insectivora, Chiroptera, Lagomorpha, Rodentia, and Carnivora; special files, including $1002 \times 2$ slides; specimens recorded in catalogues arranged numerically, by systematic groups, and by geographic areas; segregated teaching collection (200 specimens); collection used primarily in teaching; reported by Maurice M. Alexander, Professor and Chairman of Department of Forest Zoology.

\section{North Carolina}

194. North Carolina State Museum (NCSM), P.O. Box 27647, Raleigh, 27611. 900; North Carolina; Cricetinae and Leporidae; including formerly private collections of C. S. Brimley and Fred Barkalow; collection used about equally in research and exhibition; person in charge is W. L. Hamnett, Director; reported by Anne S. Bryson, Curatorial Assistant.

195. North Carolina State University (NCSU), Department of Zoology, Raleigh, 27607. $4000(+1500)$; North Carolina; Sciuridae (including known-age gray squirrels ranging in age from 1 day to 80 months that were not maintained in captivity); including 1000 skeletons and 500 bacula and/or glans; field notes; special files, including a data sheet for each specimen; specimens recorded in a catalogue arranged numerically; collection used about equally in research and teaching; reported by Fred S. Barkalow, Jr., Professor of Zoology and Forestry.

196. Wake Forest University (WFU), Department of Biology, Winston-Salem, 27109. $275(+10)$; southeastern United States; Rodentia; collection used primarily in teaching and reference; reported by Peter D. Weigl, Assistant Professor of Biology.

\section{North Dakota}

197. North Dakota State University (NDSU), Zoology Department, Fargo, 58102. $1500(+25)$; eastern North Dakota (including specimens collected by Vernon Bailey); Cricetidae; some field notes; specimens recorded in a catalogue arranged numerically and partially by systematic groups; segregated teaching collection (100 specimens); collection used primarily in teaching; reported by J. Frank Cassel, Chairman of Zoology.

198. University of North Dakota (UNDAK), Department of Biology, Grand Forks, 58201. $1846(+100)$; North Dakota, northwestern Minnesota, and southern Mexico; Sciuridae, Geomyidae, and Cricetidae; including 100 karyotypic preparations; field notes; specimens recorded in a catalogue arranged numerically, and cross-referenced for various catagories on keysort punch cards; segregated teaching collection (200 specimens); collection used primarily in teaching; reported by Robert W. Seabloom, Associate Professor.

\section{Ohio}

199. Bowling Green State University (BGSU), Department of Biology, Bowling Green, 43403. $1862(+150)$; northwestern Ohio; Peromyscus leucopus; including 100 mounted specimens; specimens recorded in catalogues arranged numerically and by geographic areas; collection used primarily in teaching; reported by Stephen H. Vessey, Assistant Professor of Biology.

200. Cleveland Museum of Natural History ( $\mathrm{CMNH}$ ), Wade Oval, University Circle, Cleveland, 44106. 18,600 ( +1000$)$; 13,410 from North America (especially Ohio), remainder (Hamann-Todd Collection) world-wide in scope; Rodentia and Primates (including 3000 humans and 1000 other primates); including 4500 skeletons, 250 mounted specimens, and 3000 specimens (primarily human) of known age; some field notes and photographs; specimens recorded in catalogues arranged numerically and by systematic groups; including Hamann-Todd Collection previously at Western Reserve University; collection used primarily in research; reported by Patricia Helwig (Curator of Collections) and Laurence Isard (Coordinator of Natural Areas). 
201. Miami University, Department of Zoology (MUDZ), Oxford, 45056. 310; southwestern Ohio; Sciuridae and Cricetidae; collection used primarily in teaching; reported by Paul M. Daniel.

202. Ohio State University, Museum of Zoology (OSUMZ), Columbus, 43210. 4100 (+350); Ohio; Peromyscus, Microtus, Myotis, Tamias, Sciurus, and Blarina; including 500 skeletons; recent field notes; specimens recorded in catalogues arranged numerically and by systematic groups; segregated teaching collection (1891 specimens); collection used primarily in research and secondarily in teaching; reported by Jerry D. Hall, Visiting Curator of Mammals.

203. Ohio University (OHIO), Department of Zoology and Microbiology, Athens, 45701. $713(+200)$; southeastern Ohio; Rodentia, Chiroptera, and Insectivora; file cards of field notes; collection used primarily in teaching and secondarily in research; person in charge is Henri Seibert; reported by Gerald E. Svendsen, Assistant Professor.

\section{Oklahoma}

204. Troy L. Best Collection (TLBC); 200; New Mexico and Oklahoma; Rodentia; field notes; collection used primarily in teaching; reported by owner (address: Department of Zoology, University of Oklahoma, Norman, 73609).

205. Cameron College (CAMCO), Biology Department, Lawton, 73501. 342; southwestern Oklahoma and Black Mesa region; Rodentia, Soricidae, and Chiroptera; collection used primarily in teaching; reported by Jack D. Tyler, Associate Professor of Biology.

206. Central State University (CSUO), Deparmtent of Biology, Edmond, 73034. 329; Oklahoma; Rodentia and Carnivora; field notes; collection used primarily in teaching; reported by Charles M. Drabek, Assistant Professor of Biology.

207. East Central State College (ECSCO), Department of Biology, Ada, 74820. 470; local representation ( 50 genera); collection used primarily in teaching; reported by William A. Carter, Professor of Biology.

208. Northeastern State College (NESCO), Tahlequah, 74464. 950; northeastern Oklahoma; Chiroptera and Rodentia; including 180 microscopic preparations, 36 tracks, and 360 skeletal remains from owl pellets; collection used primarily in teaching; reported by Everett M. Grigsby, Assistant Professor of Biology.

209. Oklahoma State University (OSU), Museum of Natural and Cultural History, Stillwater, 74074. $9500(+300) ; 1$ holotype; Oklahoma and Ethiopia; Chiroptera, Rodentia, Carnivora, and Insectivora; including 150 specimens in alcohol; field notes; specimens recorded in catalogues arranged numerically and by systematic groups; collection used primarily in teaching and secondarily in research; reported by Bryan P. Glass, Director.

210. Southeastern State College (SESCO), Biology Department, Durrant, 74701. 400 $(+100)$; southeastern Oklahoma; Rodentia; field notes (since 1969); segregated teaching collection; collection used primarily in teaching; reported by W. Frank Wade, Associate Professor.

211. University of Oklahoma (OU), Stovall Museum of Science and History, Norman, 73069. 11,000 $(+400)$; Oklahoma; Rodentia; including 500 specimens in alcohol, 400 skeletons, 100 karyotypic preparations, 50 mounted specimens, 50 specimens of known age, 30 domestic animals, and 200 bacula and/or glans; field notes; specimens recorded in a catalogue arranged numerically; collection used primarily in research; reported by John Keever Greer, Director.

212. University of Tulsa (TULSA), Life Sciences Department, Tulsa, 74100. 150; Oklahoma; Rodentia; collection used entirely in teaching; reported by Hague L. Lindsay, Associate Professor of Zoology.

\section{Oregon}

213. Ray Albright Collection (RAC); 400; Oregon; Rodentia; field notes; collection used primarily in teaching and exhibition; reported by owner (address: Rt. 1, Box 277, Dayton, 97114). 
214. Crater Lake National Park (CLNP), Crater Lake, 97604. 360; Cascade range of southern Oregon; Rodentia and Carnivora; collection used primarily in research; reported by James H. Holcomb, Park Naturalist.

215. Oregon State University, Museum of Natural History (OSMNH), Corvallis, 97331. 2500; Pacific Northwest; Rodentia; specimens recorded in catalogues arranged numerically, by systematic groups, and by geographic areas; will include the Alex Walker Collection; collection used primarily in teaching although Alex Walker Collection is reserved for research; person in charge is Robert M. Storm; reported by P. Mike Lais, Assistant Curator.

216. Southern Oregon College (SOMNH), Department of Biology, Ashland, 97520. $1000(+125)$; southwestern Oregon; Eutamias, Sciurus, Insectivora, and Chiroptera; specimens recorded in catalogues arranged numerically and by systematic groups; including Carl Richardson Collection; segregated teaching collection (109 specimens); collection used primarily in teaching; reported by Stephen P. Cross, Associate Professor of Biology.

217. University of Oregon, Museum of Natural History (UOMNH), Eugene, 97403. 2000; Pacific Northwest; Rodentia; field notes; specimens recorded in a catalogue arranged numerically; including A. C. Shelton Collection; collection used about equally in student research, teaching, public service, and exhibition; reported by Laurence R. Kittleman, Acting Director.

218. Alex Walker Collection (WC); 1000; Oregon and Southern Arizona; Sciuridae and Mustela; field catalogues; specimens recorded in a catalogue arranged by systematic groups; collection used entirely in research; owner is "in the process of depositing my collection at the Natural History Museum, Zoology Department, Oregon State University, as a permanent loan for research only, not classroom use." Reported by owner (address: Tillamook County Pioneer Museum, Tillamook, 97141).

\section{Pennsylvania}

219. Carnegie Museum of Natural History (CM), 4400 Forbes Avenue, Pittsburgh, 15213. 55,000 $(+15,000)$; 30 holotypes; Pennsylvania, Utah, Colorado, Wyoming, northern Quebec, Cameroun, Ethiopia, Kenya, and Bolivia; Blarina, Sorex, Eutamias, Dicrostonyx, Lemmus, Peromyscus, Microtus, Alopex, Mustela, Phoca, and Odocoileus; including 2000 specimens in alcohol, 10,000 skeletons, 500 mounted specimens, and 200 bacula and/or glans; field notes; special files, including some photographs, color transparencies, $2 \times 2$ slides, motion pictures, and a few lantern slides; specimens recorded in a catalogue arranged numerically; including the Karl W. Haller Collection and at least part of the collection formerly at the University of West Virginia; collection used primarily in research; reported by Duane A. Schlitter, Associate Curator of Mammals.

220. Pennsylvania State University (PSU), Forest Resources Laboratory, University Park, 16802. $1500(+100)$; Pennsylvania; Sciuridae and Cricetidae; specimens recorded in a catalogue arranged numerically; segregated teaching collection (70 specimens); collection used primarily in teaching and secondarily in research; reported by Robert G. Anthony, Assistant Professor of Wildlife Management.

221. Philadelphia Academy of Natural Sciences (ANSP), 19th and The Parkway, Philadelphia, 19103. 21,000; 157 holotypes; North and South America, Africa, and Asia; Rodentia, Carnivora, and Insectivora; including 150 specimens in alcohol and 100 mounted specimens; specimens recorded in catalogues arranged numerically, by systematic groups, and by geographic areas; including the collections of E. D. Cope, S. N. Rhoads, H. Allen, and the Wistar Institute plus the Morton Scull Collection of human skeletal materials, which is now on permanent loan to the University of Pennsylvania Museum; segregated teaching collection ( 50 specimens); collection not used much at present, but the primary goals of the collection are research and teaching; person in charge is Richard D. Estes, Chairman of Mammal Department; reported by Howard J. Ferren II, Curatorial Assistant. 
222. Reading Public Museum and Art Gallery (RPMAG), 500 Museum Road, Reading, 19602. $5000(+200)$; eastern Pennsylvania; Talpidae, Soricidae, and Vespertilionidae; including 500 skeletons, 100 microscopic preparations, and 200 mounted specimens; specimens recorded in a catalogue arranged numerically; segregated teaching collection (100 specimens); collection not used much at present (except in exhibition), although the primary goal of the collection is research; person in charge is J. Daniel Selig, Director; reported by Stephen H. Schwartz, Curator of Natural and Social Sciences.

223. Shippensburg State College (SSC), The Vertebrate Museum, Shippensburg, 17257. $1300(+25)$; south-central Pennsylvania and the Adirondack Mountains of New York; Rodentia, Mephitis, and Soricidae; including specimens in alcohol, skeletons, specimens of known age, and domestic animals; field notes; specimens recorded in a catalogue arranged numerically; segregated teaching collection; collection used primarily in research; reported by Gordon L. Kirkland, Jr., Curator and Associate Professor of Biology.

224. Wagner Free Institute of Science (WFIS), 17th Street and Montgomery Avenue, Philadelphia, 19121. 150; general representation; collection used primarily in teaching and secondarily in exhibition; reported by Robert Chambers, Director.

\section{Puerto Rico}

225. University of Puerto Rico (PRICO), Department of Biology, Mayaguez, 00708. 206; general representation from North and Central America; collection used primarily in teaching; person in charge is Virgilio Biaggii; reported by Yesmín Aymat de Figueva, Professor.

\section{South Carolina}

226. Charleston Museum (CHM), 121 Rutledge Avenue, Charleston, 29401. 1425 $(+15)$; reported in 1963 to include 3700 specimens and 3 holotypes; South Carolina; Insectivora, Rodentia, and Cetacea; including 150 skeletons; some field notes; specimens recorded in catalogues arranged numerically and by systematic groups; including Robert H. Coleman Collection; collection used primarily in research; reported by Albert E. Sanders, Curator of Natural History.

\section{South Dakota}

227. South Dakota State University (SDAKS), Entomology-Zoology Department, Brookings, 57006. 1850; general representation from South Dakota; specimens recorded in a catalogue arranged numerically; collection used primarily in teaching; reported by Ernest J. Hugghins, Professor of Entomology-Zoology.

228. University of South Dakota (USDAK), The W. H. Over Museum, Vermillion, 57069. 151; South Dakota; most specimens mounted; collection used entirely in exhibition; reported by June Sampson, Director.

229. N. R. Whitney Collection (NRWC); $100(+10)$; western South Dakota; Rodentia and Chiroptera; field notes; special files, including 200 photographs of habitats; collection used primarily in documentation; reported by owner (address: 633 South Berry Pines Road, Rapid City, 57701).

\section{Tennessee}

230. University of Tennessee (UTENN), Zoology Department, Knoxville, 37916. 500; presumably including a part of the collection formerly at the Great Smoky Mountains National Park; collection used entirely in teaching; reported by J. C. Howell, Professor of Zoology.

\section{Texas}

231. Angelo State University (ASVRC), Department of Biology, San Angelo, 76901. $1000(+50)$; Texas; Lagomorpha, Cricetidae, Vulpes, and Lynx; specimens recorded in catalogues arranged numerically and by collectors; collection used primarily in research and graduate-level teaching; reported by Wilmot A. Thornton, Professor of Biology. 
232. Austin College (AUSCO), Department of Biology, Sherman, 75090. 250; southwestern United States; Rodentia; collection used entirely in teaching; reported by Howard McCarley, Professor of Biology.

233. Baylor University, Strecker Museum (BUSM), Waco, 76703. $1145(+50)$; Texas; general representation of families; field notes; specimens recorded in a catalogue arranged numerically; collection used primarily in exhibition; reported by Bryce C. Brown, Director.

234. Dallas Museum of Natural History (DMNHT), P.O. Box 26193, Fair Park Station, Dallas, 75226. $2093(+100)$; Texas; Rodentia; including 300 mounted specimens and 116 bacula and/or glans; field notes (since 1970); specimens recorded in catalogues arranged numerically and by systematic groups; collection used primarily in teaching and exhibition; reported by William E. Wilson, Curator of Mammals.

235. James Diersing Collection (JDC); 1000; north-central Texas; Peromyscus, Neotoma, Spermophilus, Sylvilagus, and Dipodomys; field notes; specimens recorded in a catalogue arranged numerically; reported by owner (address: Star Route, Graford, 76045).

236. Fort Worth Museum of Science and History (FWMSH), 1501 Montgomery Street, Fort Worth, 76107. $1837(+50)$; Texas; Rodentia; field notes; specimens recorded in catalogues arranged numerically, by systematic groups, and by geographic areas; segregated teaching collection (250 specimens); collection used about equally in teaching and research; reported by William J. Voss, Curator of Science.

237. Hardin-Simmons University (HSIMU), Department of Biology, Abilene, 79601. 325; local Neotoma, Peromyscus, Sigmodon, and Perognathus; segregated teaching collection; collection used primarily in teaching; reported by George A. Newman, Assistant Professor.

238. Midwestern University (MWU), Department of Biology, Wichita Falls, 76308. 10,000 ( +1000); Texas, northeastern New Mexico, Mexico, and Mozambique; Rodentia and Chiroptera; including 1000 skeletons; field notes; specimens recorded in a catalogue arranged numerically; collection used primarily in research; reported by Walter W. Dalquest, Professor of Biology.

239. North Texas State University (NTSU), Department of Biological Sciences, Denton, 76201. $2000(+200)$; Texas, New Mexico, and Mexico; Peromyscus and Neotoma; including 100 specimens in alcohol and 1000 karyotypic preparations; field notes; special files, including 100 color transparencies; specimens recorded in a catalogue arranged numerically; segregated teaching collection (100 specimens); collection used primarily in research and secondarily in teaching; reported by Earl G. Zimmerman, Assistant Professor of Biology.

240. Pan American University (PANAM), Department of Biology, Edinburg, 78539. $500(+300)$; lower Rio Grande Valley; Rodentia; field notes; segregated teaching collection (200 specimens); collection used primarily in teaching; reported by Frank W. Judd, Assistant Professor of Biology.

241. Panhandle Plains Historical Museum (PPHM), Box 786, W. T. Station, Canyon, 79016. 500; southern High Plains of Texas; Rodentia; including 100 specimens in formalin; field notes; collection used primarily in exhibition; reported by Billy $\mathbf{R}$. Harrison, Curator of Anthropology.

242. Sul Ross State University (SRSU), Department of Biology, Alpine, 79830. 1055 $(+20)$; Trans-Pecos Texas and the Chihuahuan Desert; Peromyscus, Spermophilus, and Dipodomys; field notes; specimens recorded in catalogues arranged numerically and by systematic groups; segregated teaching collection ( 100 specimens); collection used about equally in research and teaching; reported by James F. Scudday, Associate Professor of Biology.

243. Tarleton State University (TSU), Department of Biological Sciences, Stephenville, 76402. $270(+100)$; north-central Texas; Rodentia; collection used primarily in teaching; reported by Herschel W. Garner, Assistant Professor. 
244. Texas A \& I University (TAIU), Biology Department, Kingsville, 78363. 300 $(+100)$; southern Texas; Rodentia; collection used primarily in teaching; reported by Allan H. Chaney, Professor of Biology.

245. Texas A \& M University, Texas Cooperative Wildlife Collections (TCWC), College Station, 77843. 27,000 ( +200); 36 holotypes; western United States, Mexico, and Central America; Chiroptera and Rodentia; including 1000 specimens in alcohol, skeletons, and karyotypic preparations; field notes; specimens recorded in catalogues arranged numerically, by systematic groups, and by geographic areas; including W. B. Davis Collection; segregated teaching collection; collection used primarily in research and secondarily in teaching; reported by W. B. Davis, Professor Emeritus, and David J. Schmidly, Curator of Mammals.

246. Texas Memorial Museum-University of Texas at Austin, Texas Natural History Collection (TNHC), 24th and Trinity, Austin, 78705. 6700 (+400); Texas and southwestern United States; Geomyidae, Heteromyidae, and Cricetidae; some field notes; specimens recorded in a catalogue arranged numerically; includes the A. J. Kirn Collection; collection used primarily in research; reported by Robert F. Martin, Curator of Vertebrates.

247. Texas Memorial Museum-University of Texas at Austin, Vertebrate Paleontology Laboratory (TMM), Balcones Research Center, Rt. 4, Box 189, Austin, 78757. $3811(+100)$; Texas, South Africa, and Australia; Carnivora and Equus zebra; predominantly skeletal materials; specimens recorded in catalogues arranged numerically and by systematic groups; collection used primarily in teaching; reported by Wann Langston, Jr., Director.

248. Texas Tech University (TTU), The Museum, Lubbock, 79409. 23,000 (+2000); 1 holotype; Llano Estacado, Neotropical region, southwestern United States, and northern Mexico; Chiroptera and Rodentia (especially Geomyidae); including 4000 specimens in alcohol, 1500 skeletons, 3000 karyotypic preparations, and 300 bacula and/or glans; field notes; specimens recorded in a catalogue arranged numerically; segregated teaching collection ( 250 specimens); collection used primarily in research; reported by Hugh H. Genoways, Curator of Mammals.

249. Texas Wesleyan College (TWC), Museum of Zoology, Ft. Worth, 76105. 429; southwestern United States; Rodentia; field notes; collection used primarily in research and secondarily in teaching; person in charge is Arthur G. Cleveland; reported by Mary E. McGhee, Assistant Curator.

250. University of Texas at Arlington, Collection of Vertebrates (UTAVC), Arlington, 76010. $1000(+20)$; north-central Texas and Veracruz; Chiroptera and Rodentia; specimens recorded in a catalogue arranged numerically; segregated teaching collection ( 50 specimens); collection used primarily in teaching; reported by J. L. Darling, Assistant Curator.

251. University of Texas at Austin, Laboratory of Physical Anthropology (UTLPA), Austin, 78712. $1500(+12)$; Texas and Kenya; Homo sapiens and Papio cynocephalus; field notes; specimens recorded in a catalogue arranged numerically; collection used primarily in teaching; persons in charge are Claud A. Bramblett and Robert M. Malina; reported by Claud A. Bramblett, Co-Director.

252. University of Texas at El Paso, Museum of Arid Land Biology (MALB), El Paso, 79968. $3630(+50)$; southwestern United States; Vespertilionidae and Cricetidae; including 100 specimens in alcohol, 3000 skeletons, and 50 domestic animals; field notes; specimens recorded in catalogues arranged numerically, by systematic groups, and, in part, by geographic areas; collection used primarily in research and secondarily in teaching; reported by Arthur H. Harris, Curator of Mammals.

253. Wayland Baptist College (WBC), Llano Estacado Museum, Plainview, 79072. $1000(+125)$; Llano Estacado, southwestern United States, and Mexico; Peromyscus; including 150 karyotypic preparations and 150 specimens of known age; field notes; specimens recorded in catalogues arranged numerically, by systematic groups, and by geographic 
areas; segregated teaching collection ( 35 specimens); collection used almost equally in research and teaching; reported by J. Hoyt Bowers, Associate Professor of Biology and Curator of Natural History Collection.

254. Welder Wildlife Foundation (WWF), P.O. Drawer 1400, Sinton, 78387. 460; southern Texas; regionally synoptic; field notes; collection used primarily in research and secondarily in teaching; reported by Gene W. Blacklock, Museum Curator.

\section{Utah}

255. Brigham Young University (BYU), Life Sciences Museum, Provo, 84602. 5250 $(+30)$; Utah and intermountain West; Rodentia; including 150 skeletons and 230 mounted specimens; field notes; special files, including $1002 \times 2$ slides; specimens recorded in catalogues arranged numerically and by systematic groups; segregated teaching collection (400 specimens); collection used about equally in research and teaching; reported by Clyde L. Pritchett, Curator of Mammals.

256. Bryce Canyon National Park (BCNP), Bryce Canyon, 84717. 111; local Rodentia and Chiroptera; collection used primarily in teaching and exhibition; reported by Robert C. Reyes, Supervisory Park Ranger.

257. Dixie College (DCU), St. George, 84770. 700; southwestern Utah; Rodentia; field notes; collection used entirely in teaching; reported by Andrew H. Barnum, Professor of Biology.

258. Timpanogos Cave National Monument (TCNM), Rt. 2, Box 200, American Park, 84003. 225; American Park Canyon in Wasatch Mountains; Rodentia and Artiodactyla; including 200 skeletons; field notes; primary goal of collection is research, but collection is used about equally in exhibition and public service; reported by Neal Bullington, Park Naturalist.

259. University of Utah ( UU ), Department of Biology, Salt Lake City, 84112. 27,800 $(+200) ; 40$ holotypes; Utah; Rodentia (especially Thomomys) and Carnivora; including 100 skeletons; field notes; specimens recorded in a catalogue arranged numerically; including the collection of the U.S. Army Proving Ground at Dugway; collection used primarily in research; reported by James H. Brown, Associate Professor of Biology.

260. Utah State University (USU), Department of Biology, Logan, 84322. 1750; northern Utah; Microtinae, Geomyidae, Peromyscus, Sciuridae, and Lagomorpha; specimens recorded in catalogues arranged numerically and by systematic groups; segregated teaching collection ( 50 specimens); collection used primarily in teaching; reported by Emily C. Oaks, Assistant Professor of Biology.

261. Weber State College (WEBSC), Department of Zoology, Ogden, 84403. 1960; Utah; Rodentia; field notes; segregated teaching collection (170 specimens); collection used primarily in teaching; reported by Earl A. Jenne, Assistant Professor of Zoology.

\section{Vermont}

262. Fairbanks Museum of Natural Science (FMNS), St. Johnsbury, 05819. 180; northeastern United States; collection used about equally in teaching and exhibition; person in charge is Frederick H. Mold, Director; reported by Howard B. Reed, Jr., Director of Education.

263. George L. Kirk Collection (GLKC); 512 entries in catalogue, but some of these specimens were destroyed or donated to other collections; Vermont; owner deceased; reported by Mrs. George L. Kirk (address: 8 East Washington Street, Rutland, 05701).

264. Lyndon State College (LSCV), Department of Science, Lyndonville, 05851. $414(+75)$; northern Vermont; Cricetidae and Insectivora; collection used primarily in teaching; reported by Don H. Miller, Chairman.

265. University of Vermont (UVMZ), Department of Zoology, Burlington, 05401. $1000(+200)$; Vermont; Rodentia and Chiroptera; including 100 specimens in buffered 
formalin; field notes; specimens recorded in a catalogue arranged numerically; including Chiroptera formerly in Harold B. Hitchcock Collection; collection used about equally in research and teaching; reported by Charles A. Woods, Assistant Professor of Zoology.

\section{Virginia}

266. Mountain Lake Biological Station (MLBS), Rt. 1, Pembroke, 24136. 300; mountains of Virginia; Rodentia; collection used primarily in teaching; persons in charge are J. J. Murray, Jr., and J. R. Riopel, Co-Directors; reported by J. J. Murray, Jr. (address: Department of Biology, University of Virginia, Charlottesville, 22903).

267. Shenandoah National Park (SNP), Luray, 22835. 107; Blue Ridge Mountains; general representation; field notes; collection used primarily in reference; person in charge is E. Ray Schaffner; reported by Kenneth Apschnikat, Central District Naturalist.

268. Virginia Polytechnic Institute and State University (VPISU), Center for Systematics Collections, Blacksburg, 24061. 4535; synoptic North American representation; field notes; specimens recorded in a catalogue arranged numerically; including Harold H. Bailey and Leonard Llewellyn collections; collection used primarily in teaching; reported by Peter L. Dalby, Curator of Mammals, and by Henry S. Mosby, Professor of Wildlife Management.

\section{Washington}

269. Sanford R. Leffler Collection (SRLC); $473(+300)$; Pacific Northwest and California; Sciuridae, Thomomys, and Peromyscus; primarily skeletal material; field notes; collection used primarily in research and secondarily in teaching; reported by owner (address: 19412 40th Avenue W, \#417, Lynnwood, 98036).

270. National Marine Fisheries Service (NWFC), Marine Mammal Division, Naval Support Activity, Bldg. 192, Seattle, 98115. 1350; eastern North Pacific; Pinnipedia and Cetacea; including 200 pinniped skulls, 150 cetacean skulls, 500 ovaries in buffered formalin, microscopic preparations, mounted specimens, specimens of known age, bacula and/or glans, teeth, baleen, and auditory bullae and plugs; field notes; special files, including some photographs and $2 \times 2$ slides; marine mammal embryo serial slide collection (at least 5 species) formerly was the private collection of John G. Sinclair; collection used primarily in research; persons in charge are Allen A. Wolman and Clifford H. Fiscus; reported by Clifford H. Fiscus, Wildlife Biologist (Research).

271. Olympic National Park (ONP), 2800 Hurricane Ridge Road, Port Angeles, 98362. $110(+35)$; Olympic Peninsula; Rodentia; collection used primarily in public service; person in charge is Jack Rockwell, Hurricane Area Manager; reported by Bruce B. Moorhead, Research Biologist.

272. D. L. Padovan Collection (DLPC); 170; local Rodentia; reported by owner (address: 1707 8th Street, Anacortes, 98221).

273. State Department of Social and Health Services, Health Services Division (HSDW), P.O. Box 1788, Olympia, 98504. 102; Columbia Basin; Rodentia; reported by Roy Russell, Acting Supervisor of Chemical and Physical Hazards Unit.

274. University of Puget Sound (UPS), Puget Sound Museum of Natural History, Tacoma, 98416. 16,000 (+2000); northwestern North America and the Dominican Republic; Insectivora, Sciuridae, Geomyidae, Cricetinae, Microtinae, Carnivora, Pinnipedia, Chiroptera, and Capromyidae; including 800 specimens in alcohol, 100 specimens in buffered formalin, 5000 skeletons, 100 karyotypic preparations, 500 microscopic preparations, 5000 electrophoretograms, 600 specimens of known age, 30 domestic animals, 3000 bacula and/or glans, and 2000 hyoid bones; field notes; special files, including 500 photographs of specimens, 400 photographs of habitats, $50002 \times 2$ slides, several reels of motion picture film, and some x-ray photographs; specimens recorded in catalogues arranged numerically, by systematic groups, and by geographic areas; specimens of known age recorded systematically; including formerly private collections of S. G. Jewett and Robert Rausch and 
the collections of the Washington Game Department and Mount Rainier National Park; segregated teaching collection (400 specimens); collection used primarily in research and secondarily in teaching; reported by Murray L. Johnson, Curator of Mammals.

275. University of Washington, Thomas Burke Memorial Washington State Museum (BMWSM), Seattle, 98195. 3500; northwestern United States; Sciuridae and Cricetidae; including 760 skeletons or skulls alone; specimens recorded in catalogues arranged numerically and by systematic groups; segregated teaching collection (50 specimens); collection used primarily in research and secondarily in teaching; person in charge is Sievert A. Rohwer, Curator of Zoology; reported by John A. Watson, Curatorial Assistant.

276. Walla Walla College (WWC), Department of Biology, College Place, 99324. $4000(+500)$; Washington and Oregon; Rodentia and Chiroptera; field notes; specimens recorded in catalogues arranged numerically and by systematic groups; collection used about equally in research and teaching; reported by Alfred E. Perry, Associate Professor of Biology.

277. Washington Game Department (WGD), 600 N. Capitol Way, Olympia, 98501. 200; Washington; furbearers; collection used primarily in teaching game personnel; reported by J. Burton Lauckhart, Chief of Game Management Division.

278. Washington State University, Charles R. Conner Museum (CRCM), Pullman, 99163. $3450(+40)$; eastern Washington and Idaho; Rodentia and Carnivora; including 241 skeletons and 138 mounted specimens; recent field notes; specimens recorded in a catalogue arranged numerically; segregated teaching collection (291 specimens); collection used primarily in research and secondarily in teaching; reported by Richard E. Johnson, Curator and Assistant Professor.

\section{West Virginia}

279. Marshall University, West Virginia Mammal Survey Collection (WVMSC) (Conservation Commission for West Virginia), Huntington, 25701. 1500; West Virginia; Rodentia; specimens recorded in a catalogue arranged numerically; person in charge is W. Gene Frum (address: 1612 6th Avenue, Huntington, 25703).

\section{Wisconsin}

280. Jay S. Haft Collection (JSHC); 200; Massachusetts; Microtus, Peromyscus, Blarina, and Sorex; field notes; reported by owner (address: Department of Anatomy, Medical College of Wisconsin, 561 N. 15th Street, Milwaukee, 53233).

281. Milwaukee Public Museum (MPM), Vertebrate Division, 800 West Wells, Milwaukee, 53233. $7000(+1000)$; Wisconsin, Africa, and Guatemala; Rodentia, ungulates, Chiroptera, Insectivora, and Primates; including 1000 skeletons, 500 mounted specimens, and a large frozen collection (including numerous African specimens) dating back to the 1920's; field notes; special files, including photographs, $2 \times 2$ slides, and motion pictures maintained in separate photographic division; specimens recorded in catalogues arranged numerically, by systematic groups, and by geographic areas; including specimens previously cited as in H. H. T. Jackson's Wisconsin collection; collection used primarily in research and secondarily in exhibition and teaching; reported by Max A. Nickerson, Head of Vertebrate Division.

282. University of Wisconsin-Madison, Department of Wildlife Ecology (UWDWE), Madison, 53706. 600; southern Wisconsin; Mustelidae, Sciuridae, and Microtinae; including 145 mounted specimens and 200 specimens of known age; field notes; collection used primarily in teaching; person in charge is Robert A. McCabe, Chairman of Department of Wildlife Ecology; reported by Robert J. Blohm, Research Assistant.

283. University of Wisconsin-Madison, Zoological Museum (UWZM), Noland Zoology Building, Madison, 53706. $8900(+2800$, not including 1260 specimens of preserved tissues and organs of large mammals and 107,180 histological slides in W. B. Quay Collec- 
tion); 1 holotype; Wisconsin, the Americas, and Europe (in descending order of representation); Rodentia and Mustelidae; including 1000 specimens in alcohol and 3000 in buffered formalin, 2500 skeletons, 2700 karyotypic preparations, 107,180 microscopic preparations, and 100 domestic animals; field notes; specimens recorded in catalogues arranged numerically, by systematic groups, and by geographic areas; including formerly private collections of W. B. Quay, A. W. Schorger, H. V. Ogden, and W. E. Snyder; collections used primarily in research and secondarily in teaching; reported by Frank A. Iwen, Curator of Vertebrate Collections.

284. University of Wisconsin-Milwaukee (UWMIL), Zoology Department, Milwaukee, 53201. 100; Wisconsin; collection used primarily in teaching; reported by Charles M. Weise, Professor of Zoology.

285. University of Wisconsin-Stevens Point (UWSP), The Museum of Natural History, Stevens Point, 54481. 3200; 1 holotype; Wisconsin; Sciuridae, Cricetidae, Mustelidae, and Soricidae; including 300 specimens in alcohol, 800 skeletons, and 250 bacula and/or glans; field notes; specimens recorded in a catalogue arranged numerically; segregated teaching collection; collection used primarily in research and secondarily in teaching; reported by Charles A. Long, Director and Curator of Mammals.

\section{Wyoming}

286. Casper College (CCW), Biology Department, 125 College Drive, Casper, 82601. $500(+200)$; Wyoming; Rodentia, Chiroptera, and Lagomorpha; field notes; segregated teaching collection ( 50 specimens); collection used primarily in teaching; reported by James A. Howard, Zoology Instructor.

287. o. J. Murie Collection (OJMC); reported by owner (in December of 1961) to include 500 specimens; "Alaska, Canada (Hudson Bay area), western U. S., Wyoming;" owner deceased; according to Mrs. Margaret E. Murie (correspondence dated 13 January 1974), "The collection is to be given next spring to the new Environmental Education Center here in Grand Teton National Park. ..” Address of Mrs. Murie: Moose, Wyoming, 83012.

288. University of Wyoming (UWYO), The Museum of Zoology, Laramie, 82071. $2000(+700)$; Wyoming; Carnivora, Artiodactyla, and Rodentia; including reproductive tracts preserved in formalin; field notes; special files, including photographs of specimens, color transparencies, and $2 \times 2$ slides; specimens recorded in catalogues arranged numerically and by collectors; including A. M. Mickey Collection; segregated teaching collection; collection used primarily in research and secondarily in teaching; reported by Jack $\mathrm{C}$. Turner, Assistant Professor and Curator of Mammals.

289. Yellowstone National Park (YNPW), Mammoth Hot Spring, 82190. 272; local Rodentia; including 75 mounted specimens; field notes; collection used primarily in exhibition; reported by Thea K. Nordling, Park Technician (Curator).

The following list includes reporting collections of fewer than 100 specimens plus nonreporting collections included in the 1963 survey. The arrangement of data in entries for reporting collections is as above. Nonreporting collections are quoted directly from the 1963 report.

\section{Canada \\ Alberta}

290. Banff National Park (BNP), Box 900, Banff T0L 0C0. 75; local representation, lacking skulls; field notes; collection used primarily as an aid in identification; person in charge is T. R. Heggie, Superintendent; reported by Bruce Gordon, Assistant Park Naturalist. 


\section{British Columbia}

291. Fish and Game Branch (FGBBC), Kamloops. "50 properly labeled skins and study skins from B.C. used in illustrating lectures; reported by P. W. Martin, Regional Game Biologist, in November 1961."

292. Okanagan Museum and Archives Association (OMAA), Kelowna. "120 including the collection of the late Capt. J. C. Dun-Walters, some mounted, from Saskatchewan and areas to the west; reported by C. R. Walrod, Acting Curator, and member of the Board, in November 1961."

\section{Manitoba}

293. Riding Mountain National Park (RMNPC), Wasagaming. 85; local representation; collection used primarily in interpretation; person in charge is Ron Rontledge; reported by Ian R. Church, Park Naturalist.

\section{Ontario}

294. Department of Lands and Forests (DLFO), Province of Ontario, Maple. “ 3000 , most from Ontario, including skulls of wolves, coyotes and beaver; field notes; photographs; wolf howls on tape; card files; reported by R. Standfield, Biologist, Research Branch, in November 1961."

295. Ontario Agricultural College (OAC), Department of Entomology and Zoology, Guelph. "600 from Ontario, rodents and leporids best represented; some field notes; color transparencies; primarily a teaching collection; reported by A. T. Cringan, Assistant Professor, in January 1962."

296. Queen's University (QU), Department of Biology, Kingston K7L 3N6. 50; local representation; collection used primarily in teaching and secondarily in research; reported by J. A. Keast, Professor.

297. Quetico Provincial Park Museum (QPPM), Ministry of Natural Resources, Atikokan POT 1C0. 39; local representation; collection used primarily in public service; reported by Shan Walshe, Park Naturalist.

298. Howard Savage Collection (HSC), Toronto. " 200 from Ontario, including mustelids, prepared by Dr. Savage and his two sons; reported by H. Savage, M.D., in March 1962."

\section{Costa Rica}

299. Museo Nacional (MNCR), San José. “350 uncatalogued; Rodentia, Chiroptera; reported by R. G. Van Gelder (American Museum of Natural History, New York City) from information obtained from Alfonso Jiménez, in September 1962."

\section{JAMAICA}

300. Institute of Jamaica ( IJ), Collection of Mammals, Kingston. 75; Jamaica; Chiroptera and Rodentia; collection used in research; person in charge is Tom Farr.

\section{United States}

\section{Alabama}

301. Alabama Cooperative Wildlife Research Unit (ACWRU), Auburn. "100 from Alabama; photographs; reported by M. F. Baker, Unit Leader, in December 1961."

302. Auburn University (AU), Auburn. "500 from Alabama; reported by J. L. Dusi, Associate Professor, in December 1961."

\section{Alaska}

303. Glacier Bay National Monument (GBNM), Gustavus, 99826. $30(+20)$; local Soricidae, Cricetidae, and Mustelidae; field notes; collection used primarily in interpretation and secondarily in education and research; reported by Bruce B. Page, Park Naturalist. 


\section{Arizona}

304. Fish and Wildlife Service (FWSA), Ajo. "37 from Colorado and Arizona; field notes; photographic slides; reported by Norman M. Simmons in March 1962."

305. Petrified Forest National Monument (PFNM), Holbrook. "61 local specimens; reported by N. G. Messinger, Park Naturalist."

306. Saguaro National Monument (SNM), P.O. Box 17210, Tucson, 85731. 90; Sonoran Desert; Chiroptera and Rodentia; collection used primarily in exhibition; person in charge is Harold T. Cross, Chief Park Naturalist; reported by Roberta Richards, Park Technician.

307. Walnut Canyon National Monument (WCNM), Box 790, Flagstaff, 86001. 28; north-central Arizona; Chiroptera and Sciuridae; collection used primarily in teaching and exhibition; reported by Vic Vieira, Supervisory Park Ranger.

\section{Arkansas}

308. Arkansas Game and Fish Commission (AGFC), Game and Fish Building, Little Rock, 72201. 26; local representation; collection used entirely in exhibition; person in charge is Joe Hensley; reported by Lew Johnston, Game Biologist II.

\section{California}

309. Big Basin Redwoods State Park (BBRSP), Big Basin, 95006. Collection consists of 15 exhibit specimens from the Santa Cruz Mountains. Reported by Denzil R. Verardo, State Park Ranger I.

310. Bureau of Vector Control (BVCC), 217 W. 1st Street, Los Angeles. "37, mostly rodents from southern California; reported by Donald L. Rohe, Assistant Vector Control Specialist, in March 1962."

311. Diablo Valley College (DVC), Concord. "400, most from California or Okanagan, British Columbia; some special preparations; color transparencies and motion pictures; reported by F. S. Ruth, Biology Department, in March 1962."

312. G. F. Fisler Collection (GFFC); Department of Biology, San Fernando Valley State College, Northridge, 91324. "630, rodents and carnivores of Michigan and California; some special preparations; field notes; reported by owner in March 1962."

313. Lassen Volcanic National Park (LVNP), Mineral, 96063. 50; Cascade Range of northern California; Rodentia; field notes; collection used primarily in interpretive training; reported by Richard L. Vance, Chief Park Naturalist.

314. Los Angeles County Museum (LACM), Los Angeles. “'21,500, southern California, southern Mexico, New World bats, rodents, including 3,200 specimens in the Alan Hancock Foundation collection, 300 bats in the A. Starrett collection and bats from Kenneth E. Stager collection; more than 400 in preservative; some field notes; a few photographs; systematic card file; reports from A. Starrett, then of University of Southern California, and C. A. McLaughlin, Associate Curator, in November 1961."

315. Point Reyes National Seashore (PRNS), Point Reyes Station, 94956. 49; representative mammals from the Point Reyes Peninsula; field notes; collection used primarily in documentation; person in charge is William L. Germeraad, Chief Interpreter; reported by Thomas G. Vaughan, Park Naturalist.

316. W. B. Richardson Collection (WBRC), Porterville. " 400 , mostly small mammals from western U.S.; reported by owner (address, 907 E. Mill Street, Porterville) in March 1962."

317. Riverside Municipal Museum (RMM), 3720 Orange Street, Riverside, 92501. 75; southern California; mounted specimens and skeletons of Rodentia and Carnivora; field notes; collection used primarily in exhibition; reported by David T. Wright, Curator of Zoology. 
318. San Bernardino Valley College (SBVC), San Bernardino. "1,010 western Mojave Desert, San Bernardino Mountains, San Bernardino and Riverside valleys, one-third rodents; field notes; systematic card file; reported by H. R. Chandler, Head of Department of Biology, in December 1961."

319. United States Forest Service, Glendora Research Center (GRC), Glendora. “28, Los Angeles County; reported by R. M. Rice, Research Center Leader, in April 1962."

320. David B. Winters Collection (DBWC), Santa Barbara. " 25 , southern Michigan, Myotis, Peromyscus; field notes; reported by owner (address: 25 West Mission Street, \#B) in March 1962."

\section{Colorado}

Colorado College, Colorado Springs, 80900. According to D. M. Armstrong (University of Colorado), "The Warren Collection, once at Colorado College, now is in the C. U. Museum. Richard Beidleman of CC may retain a small teaching collection."

321. Colorado National Monument (CNM), Fruita. "102, from Colorado National Monument and Black Canyon of the Gunnison National Monument, small carnivores and rodents; photographs; card files; reported by P. H. Miller, Chief Park Naturalist, in December 1961."

322. University of Northern Colorado (UNCOL), Department of Biology, Greeley, 80631. "125, Weld County, Rodentia, Carnivora; reported by M. N. Stamper, Professor, in November 1961."

323. Denver Museum of Natural History (DMNHC), City Park, Denver, 80205. The report received from A. M. Bailey (then Director) in November of 1961 was summarized (for publication) as follows: "5000, Colorado and Alaska; photographs . . ." Director Emeritus Bailey wrote on 5 August 1974 that "Our field work has been oriented toward collecting exhibit material and consequently of recent years few mammals have been added to the study series ...."

324. Dinosaur National Monument (DINO), Box 101, Dinosaur, 81610. 50; local representation; collection used primarily in interpretation; reported by Bill Truesdell.

325. Great Sand Dunes National Monument (GSDNM), P.O. Box 60, Alamosa, 81101. 30; local representation; collection used primarily for exhibition and as a repository for specimens accidentally killed within monument boundaries; reported by M. M. Dick.

Mesa Verde National Park, 81330. No longer maintains a collection of mammals according to Gil Wenger, Chief Archeologist.

\section{Connecticut}

326. Peabody Museum of Natural History, Yale University (YPM), New Haven. "7000, Connecticut, Ecuador, Kenya, includes 5000 osteological specimens of Recent mammals in the Division of Vertebrate Paleontology; systematic card file; reported by C. A. Reed, Curator, in October 1961."

327. Trinity College (TCC), Hartford. " 25 , teaching collection, mostly skeletons; reported by J. W. Burger, Professor, in October 1961.”

\section{Florida}

328. Everglades National Park (ENP), P.O. Box 279, Homestead, 33030. 50; local representation; collection used primarily in documentation and interpretation; person in charge is Alcyone Bradley, Librarian-Curator; reported by Douglas Bruce McHenry, Assistant Chief of Division of Interpretation.

\section{Idaho}

329. University of Idaho (UIDA), Department of Biological Science, Moscow. “4460, Idaho, the Pacific Northwest, Rodentia, Lepus americanus, Soricidae; some special preparations and field notes; photographs; reported by E. J. Larrison, in November 1961." 


\section{Illinois}

330. Harold E. Broadbooks Collection (HEBC), Edwardsville. "500, western North America, Rodentia; reported by owner (address: Department of Zoology, Southern Illinois University) in December 1962."

331. Chicago Academy of Sciences (CHIAS), Chicago. "4500 reported previously; no current report."

332. Natural History Museum of the Burpee Art Gallery Association (BAGA), Rockford. "70, northern Illinois, southern Wisconsin, Rodentia, Mustelidae, most mounted; reported by M. Mahlburg, Director, in November 1961."

333. Southern Illinois University-Edwardsville (SIUE), Edwardsville. "1300, southwest and northwest U.S., Illinois, Eutamias, Peromyscus, Perognathus and other Rodentia; reported by Harold E. Broadbooks, Assistant Professor, in January 1962."

334. Southern Illinois University-Carbondale, Cooperative Wildlife Research Laboratory (CWRL), Carbondale. " 3055 , southern Illinois, Rodentia, Chiroptera, Carnivora, Lagomorpha; reported by W. D. Klimstra, Director, in March 1962.”

\section{Kansas}

335. Charles A. Ely Collection (CAEC); 50; Kansas and Mexico; Rodentia and Chiroptera; collection used primarily in teaching; reported by owner (address: Museum of the High Plains, Fort Hays Kansas State College, Hays, 67601).

336. Forestry, Fish and Game Commission (KFFGC), P.O. Box 1028, Pratt, 67124. 50 mounted specimens; synoptic local representation; field notes; collection used entirely in exhibition; person in charge is Leroy E. Lyon, Chief of Information-Education Division; reported by Bev Aldrich, Secretary.

337. Kansas State Teachers College (KSTC), Emporia. "275, Kansas, Canadian Arctic Archipelago, Rodentia; some photographs; card files; reported by D. F. Parmalee, Associate Professor, in November 1961."

\section{Kentucky}

338. Western Kentucky State College (WKSC), Bowling Green. "100, northern Louisiana, Cricetidae; field notes; reported by H. E. Shadowen, Professor, in December 1961."

\section{Louisiana}

University of New Orleans, New Orleans, 70100. According to Aelita J. Pinter, there is no longer a collection of mammals at this institution (formerly Louisiana State University in New Orleans).

\section{Maine}

339. University of Maine-Farmington (UMFA), Department of Biology, Farmington, 04938. Maintains "a decent mammal collection ... with specimens from Russia, Iraq, Colombia, Turkey, and Thailand, not to mention Maine itself." Reported by Robert L. Martin, Professor of Biology.

\section{Maryland}

Patuxent Wildlife Research Center, Laurel, 20810. A small collection is maintained for food habits studies and identification purposes. It is neither curated, available for loan, or available for study. Reported by Lucille F. Stickel, Director.

\section{Missouri}

Bernard B. Butterworth Collection, School of Dentistry, University of Missouri-Kansas City, 650 E. 25th Street, Kansas City, 64108. According to the former owner, "The collection indicated on the attached form has been broken up and is now in several collections." 
340. Missouri Department of Conservation (MDC), Fish and Game Research Center, 1110 College Avenue, Columbia, 65201. 30; Missouri; including 100 hair slides and 14,000 uncatalogued bacula (10,000 are of Procyon and 3800 of Mustela vison); collection used primarily in exhibition and secondarily in research; person in charge is Bill $\mathrm{T}$. Crawford, Superintendent of the Game Research Section; reported by Leroy J. Korschgen, Research Biologist.

341. Museum of Science and Natural History (MSNH), Oak Knoll Park, Clayton, 63105. 50; including Leo Hess Collection; collection used primarily in exhibition and teaching; reported by James Houser, Curator.

342. William Jewell College (WJC), Biology Department, Liberty. " 250 , Missouri, Rodentia; some special preparations; field notes; photographs; card files; reported by L. J. Gier, Curator, and O. T. Lind, Assistant Professor, in March 1962,"

\section{Nebraska}

343. State of Nebraska, Game, Forestation, and Parks Commission (NGFPC), Lincoln. " 235 , Nebraska, Rodentia, Lagomorpha; reported by L. Vance, Chief, Game Division, in November 1961."

344. Union College (UC), Biology Department, Lincoln. “300; reported by Dr. J. Knox Jones, Jr., Lawrence, Kansas."

\section{Nevada}

345. Lake Mead National Recreation Area (LMNRA), 601 Nevada Highway, Boulder City, 89005. 75; Mojave Desert; Chiroptera and Rodentia; field notes; collection used primarily in documentation; reported by William A. Stumpf, Environmental Management Specialist.

346. University of Nevada, Reno (UNEVR), Department of Biology, Reno. "1000, western Nevada, Rodentia; systematic card file; reported by F. A. Ryser, Jr., Associate Professor, in January 1962."

\section{New Jersey}

347. Watchung Reservation (WRNJ), Trailside Museum, Union County Park Commission, Mountainside. "213, eastern North America, all mounted; photographs; reported by H. N. Moldenke, Director, in October 1961.”

\section{New Mexico}

348. Carlsbad Caverns National Park (CCNP), Carlsbad. "225, local Chiroptera, Rodentia; photographs; card files; reported by P. F. Spangle, Chief Park Naturalist, in January 1962."

349. White Sands National Monument (WSNM), P.O. Box 458, Alamogordo, 88310. 50; Tularosa Basin; Rodentia; collection used primarily in public service and personnel training; person in charge is John F. Turney, Superintendent; reported by George T. Morrison, Interpretive Specialist.

\section{New York}

350. Brooklyn Children's Museum (BCM), Brooklyn Ave. and Park Place, Brooklyn. "54, northeastern U. S.; card files; reported by O. A. White, Curator, in January 1962."

351. New York State Department of Environmental Conservation (NYSEC), Wildlife Research Laboratory, Delmar, 12054. Reported in August of 1962 as "1,000; central and northern New York; Odocoileus virginianus, Ursus americanus, known age deer embryos and skulls, known age Lepus americanus embryos, some photographs;" person in charge is C. W. Severinghaus, Supervising Wildlife Biologist. 
352. Robert K. Chipman Collection (RKCC), Plattsburgh. " 400 , including 200 known age Sigmodon from Louisiana; reported by owner (address: Department of Science and Mathematics, State College, Plattsburgh) in March 1962."

353. St. Bonaventure University (SBU), Department of Biology, St. Bonaventure. "304, southwestern New York, Odocoileus virginianus skulls, Ursus americanus skulls, Cricetidae; some special preparations; field notes; reported by S. W. Eaton, Professor, in March 1962."

354. State University College of Education, Albany (SUCEA). "350, eastern and central New York, Rodentia; reported by A. H. Benton, Associate Professor, in November 1961."

355. State University College of Education, Plattsburgh (SUCEP), Department of Science and Mathematics, Plattsburgh. "200, northeastern New York, Lagomorpha, Carnivora; reported by R. K. Chipman, Instructor, in March 1962."

356. Roslyn Museum of Natural History (RMNH), Roslyn, Long Island. " 30 , international, includes the J. T. Fox collection; photographs; systematic card file; reported by John Owen, Director of Instructional Services, in December 1962."

357. Union Free School (UFS), Deer Park, Long Island. " 25 , New York; reported by J. J. Rizza, Biology Teacher, in March 1962."

\section{North Carolina}

358. City of Burlington (CBNC), Department of Recreation and Parks. " 280 , the Dr. B. B. McDade Collection; North America, South America and Africa, especially big game; field notes; reported by J. C. Davidson, Director, Department of Recreation and Parks, in November 1961."

\section{North Dakota}

Lower Souris National Wildlife Refuge, Upham, 58789. A note from Robert C. Fields (Refuge Manager) requested that the entry for the Refuge be deleted and noted that "We have so little here it is not worth bothering with."

\section{Ohio}

359. Cincinnati Museum of Natural History (CMNHO), 1720 Gilbert Avenue, Cincinnati, 45202. According to DeVere Burt (the Associate Director), "The Museum's collection of mammals was moved sometime ago and most of it ended up at the University of Illinois. . . . Recently we have undertaken a survey project aimed at rebuilding a collection of regional importance... (but) we are in the very initial stages and obviously are in no position to respond to the questionnaire."

360. University of Cincinnati (UCIN), Department of Biological Sciences, Cincinnati. "1500, Ohio, small mammals; some field notes and photographs; card files; reported by J. L. Gottschang, Associate Professor, in March 1962."

361. Ohio Historical Society (OHS), Ohio Historical Center, Columbus, 43211. 75; synoptic representation from Ohio; including 65 uncatalogued mounted specimens; field notes; collection used primarily in teaching and as an aid in identification; reported by William T. Schultz, Assistant Curator for Natural History.

\section{Oklahoma}

362. Wichita Mountains Wildlife Refuge (WMWR), P.O. Box 448, Cache, 73527. 50; Wichita Mountains; Rodentia; field notes; collection used primarily in research; reported by Roger D. Johnson, Refuge Manager.

\section{Pennsylvania}

363. St. Vincent College (SVCP), Museum, Latrobe, 15050. 38; local representation; field notes; collection used primarily in exhibition; reported by Jerome Rupprecht, Curator. 


\section{Rhode Island}

364. Park Museum (PMRI), Roger Williams Park, Provindence. "70, mostly local, on display; reported by M. Cormack, Director, in October 1961."

\section{South Dakota}

365. Henry Brockhouse Collection (HBC), Sioux Falls. " 55 , including 45 entire mounts of big game animals, Africa, Alaska; some field notes; reported by J. P. Jonas, Jr., taxidermist (address of owner: West Sioux Hardware, 2304 West Madison), in November 1961."

366. Pettigrew Museum (PMSD), City of Sioux Falls. "30, mounted; reported by G. E. Rogers, Curator, in November 1961."

367. South Dakota Department of Game, Fish and Parks (SDGFP), Pierre. 6 (including 2 mounted specimens of Mustela nigripes); reported by B. J. Rose, Staff Game Specialist.

368. Wind Cave National Park (WCNP), Hot Springs, 57747. 50; local representation; field notes; collection used entirely in reference; reported by John C. O'Brien, Chief of Interpretation.

\section{Tennessee}

Great Smoky Mountains National Park, Gatlinburg, 37738. According to Donald H. DeFoe, Assistant Chief of Interpretation, the collection of more than 500 mammals listed in the 1963 survey has been dispersed on "indefinite loan" to the University of Tennessee, Tennessee Technological University, and Michigan Technological University.

369. State Game and Fish Commission (SGFCT), Nashville. "100, southern Appalachian Mountains, Sus scrofa; field notes; some photographs; reported by G. H. Matschke, Senior Biologist (address: Rt. 1. Madisonville, Tennessee), in March 1962."

\section{Texas}

370. Big Bend Natural History Association (BBNHA), Big Bend National Park. "67, local, Sciuridae, Heteromyidae, Cricetidae, mounted; photographs; reported by D. S. Evans, Chief Park Naturalist, in November 1961."

371. Davis Mountains State Park (DMSPT), Ft. Davis, 79734. 50; western Texas; field notes; collection used primarily in exhibition; reported by Danny Bedell, Park Superintendent.

372. Sam Houston State University (SHSU), Department of Biology, Huntsville, 77340 . $50(+40)$; local Rodentia; collection used entirely in teaching; reported by Barry Hinderstein, Assistant Professor of Biology.

373. Southern Methodist University (SMU), Department of Biology, Dallas. "307; reported by W. B. Stallcup in J. Grad. Research Center, Vol. 24, No. 1, in January 1961."

374. Stephen F. Austin State University (SFASU), Department of Biology, Nacogdoches. "2000, eastern Texas, Cricetidae, Carnivora; some special preparations; field notes; card files; reported by R. L. Packard, then Director of Vertebrate Collections, in November 1961."

375. West Texas State University (WTSU), Department of Biology, Canyon, 79016. 50; Texas Panhandle; Rodentia; collection used entirely in teaching; reported by W. A. Cooper, Professor of Biology.

\section{Utah}

376. Utah Field House of Natural History (UFHNH), Vernal State Park, Vernal. "50, local, on display; reported by G. E. Untermann, Director, in November 1961."

377. Zion National Park (ZNP), Springdale, 84767. 50; local Rodentia; collection used primarily as aid in identification; reported by Victor L. Jackson, Chief Park Naturalist. 


\section{Vermont}

Harold B. Hitcheock Collection (HBHC), 1 Locust Lane, Middlebury, 05753. A note from Harold Hitchcock states, "I have disposed of all specimens to various museums, including MCZ, USNM, RMZ and University of Vermont."

378. Donald H. Miller Collection (DHMC); 50; Vermont; reported by owner (address: Department of Science, Lyndon State College, Lyndonville, 05851).

\section{Virginia}

379. Bridgewater College (BCV). " 80 , local, Peromyscus; reported by H. G. M. Jopson, Professor, in March 1962."

380. University of Virginia (UVIRG), The Seward Forest, Triplet, 23886. 30; local representation; field notes; collection not being used at present; reported by Guy Estes, Director.

\section{Washington}

381. Irven O. Buss Collection (IOBC), Pullman. "100, Wisconsin, Mustelidae; field notes; some photographs; reported by owner (address: Department of Zoology; Washington State University) in March 1962."

382. J. LeRoy Fish Collection (JLFC) (address unknown). According to Alfred E. Perry (Walla Walla College), this collection is no longer at Walla Walla College.

383. Pacific Lutheran College (PLC), Department of Biology, Tacoma. " 350 , western Washington, small mammals, in part the personal collection of Dr. Leraas; some field notes; systematic card file; reported by H. J. Leraas, Professor, in November 1961.”

384. State of Washington, Department of Health (WDH), Public Health Building, Seattle. "115, Columbia Basin of Washington, Rodentia; reported by Roy J. Myklebust, Advisory Sanitarian, in March 1962."

385. Whitman College (WCW), Walla Walla. "400, Pacific Northwest, Rodentia, includes the Storres-Lyman Collection; some field notes; reported by J. Cadigan, in November 1961."

\section{West Virginia}

386. W. Gene Frum Collection (WGFC), Huntington. "1700, eastern U. S., Myotis; reported by owner (address: 311 Holswade Drive) in December 1961."

\section{Wisconsin}

387. Wisconsin Conservation Department (WISCD), Plainfield. "150, Wisconsin, Iowa, reported by F. Hamerstrom, in November 1961."

\section{Wyoming}

388. Grand Teton National Park (GTNP), Box 67, Moose, 83012. 24; northwestern Wyoming; small mammals; presently not in use; person in charge is C. H. McCurdy, Chief Park Naturalist; reported by Bob Wood, Resources Management Specialist.

The following list includes the names and addresses of institutions and persons suspected of having collections but about which no data were obtained. Persons interested in mammals from their local area should consult these institutions or persons, about the availability of specimens.

\footnotetext{
University of Costa Rica, Department of Biology, Ciudad Universitaria, Costa Rica.

Universidad de Nuevo Leon, Facultad de Ciencias Biologicas, Ciudad Universitaria, Apartado Postal 2790, Monterrey, Nuevo Leon, Mexico.

Morro Bay State Park, Rt. 2, Box 426, San Luis Obispo, California 93401.

Southern Colorado State College, Department of Biology, Pueblo, Colorado 81003.
} 
University of Georgia, School of Forest Resources, Athens, Georgia 30601.

Eastern Illinois University, Charleston, Illinois 61920.

Knox College, Galesburg, Illinois 61401.

Northern Illinois University, DeKalb, Illinois 60115.

Rockford College, Department of Biology, Rockford, Illinois 61101.

Buena Vista College, Department of Biology, Storm Lake, Iowa 50588.

Iowa Historical Museum, Des Moines, Iowa 50300.

Morningside College, Department of Biology, Sioux City, Iowa 51100.

Sanford Museum, Cherokee, Iowa 51012.

Maine State Museum, State House, Augusta 04330.

University of Maryland, Natural Resources Institute, College Park, 20740.

Delta College, Department of Biology, University Center, Michigan 48710.

Eastern Michigan University, Department of Biology, Ypsilanti, Michigan 48197.

Gogebic Community College, Ironwood, Michigan 49938.

Kalamazoo College, Department of Biology, Kalamazoo, Michigan 49001.

Northern Michigan University, Department of Biology, Marquette, Michigan 49855.

Western Michigan University, Department of Biology, Kalamazoo, Michigan 49007.

New Mexico Highlands University, Department of Biology, Las Vegas, New Mexico 87701.

Northern Prairie Wildlife Research Center, Box 1747, Jamestown, North Dakota 58401.

State Historical Museum, Bismarck, North Dakota 58501.

Dayton Museum of Natural History, Dayton, Ohio 45400.

Defiance College, Department of Biology, Defiance, Ohio 43512.

Woodrow W. Goodpaster (Address: 6559 Salem Pike, Cincinnati, Ohio 45230). Reported by D. F.

Hoffmeister (University of Illinois) to have a private collection.

Kent State University, Department of Biology, Kent, Ohio 44240.

Marietta College, Department of Biology, Marietta, Ohio 45750.

Muskingum College, Department of Biology, New Concord, Ohio 43762.

University of Akron, Department of Biology, Akron, Ohio 44300.

Cameron State College, Lawton, Oklahoma 73501.

Northern Oklahoma College, Department of Biology, Tonkawa, Oklahoma 74653.

Northwestern State College, Alva, Oklahoma 73717.

Shawnee Baptist University, Shawnee, Oklahoma 74801.

Southwestern State College, Department of Biology, Weatherford, Oklahoma 73096.

Tillamook County Pioneer Museum, Tillamook, Oregon 97141. According to Alexander Walker

(Curator of Museum), this museum has "a few dozen" mammals (with data) on exhibit.

Slippery Rock State College, Department of Biology, Slippery Rock, Pennsylvania 16057.

East Texas State University, Department of Biology, Commerce, Texas $\mathbf{7 5 4 2 8 .}$

Howard Payne College, Department of Biology, Brownwood, Texas 76901.

Wiley College, Department of Biology, Marshall, Texas 75670.

Witte Museum, San Antonio, Texas 78200.

\section{INDEX}

$-\mathrm{A}-$

Acadia University Museum, 9, 10

Adams, L. A., 96

Adams State College, 70

Alabama

Cooperative Wildlife Research Unit, 301

Department of Conservation and Natural Resources, 24

Alan Hancock Foundation, 314

Alaska Department of Fish and Game, 27, 29

Albright, R., 213

Alcorn, J. R., 173

Algonquin Provincial Park, 11

Allen, H., 221

American Museum of Natural History, 186

Angelo State University, 231
Archbold Biological Station, 82

Arizona State University, 30

Arkansas

Game and Fish Commission, 308

State University, 38

Auburn University, 302

Austin College, 232

$$
-B \text { - }
$$

Bailey, H. H., 268

Banff National Park, 290

Banfield, A. W. F., 17

Bangs, O., 132

Barbehenn, K. R., 159

Barkalow, F., 194

Batchelder, C. F., 132

Baylor University, 233

Beare, G. E., 17 
Bemidji State College, 151

Bernice P. Bishop Museum, 89

Best, T. L., 204

Big Basin Redwoods State Park, 309

Big Bend Natural History Association, 370

Bird and Mammal Laboratories, 81

Blagen, W., 105

Boston University, 131

Bowen, W. W., 86

Bowling Green State University, 199

Bridgewater College, 379

Brigham Young University, 255

British Columbia Provincial Museum, 3

Brimley, C. S., 194

Broadbooks, H. E., 330

Brockhouse, H., 365

Brooklyn Children's Museum, 350

Brooks, A. C., 2

Brooman, R. C., 12

Brown, N. R., 8

Bryce Canyon National Park, 256

Bureau of Vector Control, 310

Buss, I. O., 381

$$
-\mathrm{C}-
$$

California

Academy of Sciences, 41

Polytechnic State University, 42

State College, 43

State Polytechnic University, 44

California State University,

Fresno, 45

Fullerton, 46

Long Beach, 47

Los Angeles, 48

Sacramento, 49

Cameron College, 205

Carleton University, 13

Carlsbad Caverns National Park, 348

Carnegie Museum of Natural History, 219

Casper College, 286

Centenary College, 121

Central College, 101

Central Michigan University, 139

Central Missouri State University, 160

Central State University, 206

Charleston Museum, 226

Chemical Control Research Institute, 14

Chicago Academy of Sciences, 331

Chico State University, 50

Chipman, R. K., 352

Cincinnati Museum of Natural History, 359
City of Burlington, 358

Cleveland Museum of Natural History, 148, 200

Coe College, 102

Coleman, R. H., 226

Colgate University, 187

Colorado

National Monument, 321

State University, 71

Cope, E. D., 221

Copeland, M., 132

Cornell University, 188

Cowan, I. McT., 2

Cowles, R. B., 68

Cranbrook Institute of Science, 140

Crater Lake National Park, 214

Cutter, W., 115

$$
-\mathrm{D}-
$$

Dalquest, W. W., 115

Dallas Museum of Natural History, 234

Dartmouth College Museum, 177

Davenport Museum, 103

Davis, E., 17

Davis, W. B., 245

Davis, W. H., 117

Davis Mountains State Park, 371

Death Valley National Monument, 51

Delaware Museum of Natural History, 79

Denver

Food Habits Laboratory, 76

Museum of Natural History, 323

Wildlife Research Center, 76

Department of Lands and Forests, 294

Diablo Valley College, 311

Dickey, D. R., 64, 68, 148

Diersing, J., 235

Dinosaur National Monument, 324

Dixie College, 255

Douglas, C. L., 174

Dun-Walters, J. C., 292

$$
-\mathrm{E}-
$$

Earlham College, 98

East Central State College, 207

Eastern Kentucky University, 118

Eastern New Mexico University, 180

Ellis, R., 115

Ely, C. A., 335

Escuela Nacional de Ciencias Biologicas, 22

Everglades National Park, 328 


$$
-\mathrm{F}-
$$

Fairbanks Museum of Natural Science, 262

Fassler, D. J., 163

Field Museum of Natural History, 91

Fish, J. L., 382

Fish and Game Branch, 291

Fish and Wildlife Service, 304

Fisler, G. F., 312

Fleming, J. H., 17

Florida State University, 83

Forest Entomology Laboratory, 14

Forestry, Fish, and Game Commission, 336

Fort Hays Kansas State College,

Museum of the High Plains, 108

Sternberg Memorial Museum, 109

Fort Lewis College, 72

Fort Niobrara National Wildlife Refuge, 168

Friends University, 110

Frum, W. G., 386

Fort Worth Museum of Science and History, 236

$$
-G-
$$

Garnier, J. H., 17

Garret, C. B., 17

Geist, O. W., 29

Georgetown College, 119

Glacier National Park, 164

Goodpaster, W. W., 96

Gordon, D. C., 189, 191

Grand Canyon National Park, 31

Grand Rapids Public Museum, 141

Grand Teton National Park, 388

Great Sand Dunes National Monument, 325

Great Smoky Mountains National Park, 145, 230

$$
-\mathrm{H}-
$$

Haft, J. S., 280

Haller, K. W., 219

Hamann-Todd Collection, 200

Hardin-Simmons University, 237

Hardy, R., 47

Harvard University, 132

Hastings Museum, 167

Hastings Natural History Reservation, 52

Hemphill, D. V., 56

Hildebrand, M., 53

Hitchcock, H. B., 265

Hope College, 142

Hoslett, S., 105
Howell, A. B., 68

Huey, L. M., 58

Humboldt State University, 54

$$
-\mathrm{I}-
$$

Idaho State University, 90

Illinois

Natural History Survey, 92

State Museum, 93

State University, 94

Indiana State University, 99

Institute of Jamaica, 300

Iowa State University, 104

$$
-\mathrm{J}-
$$

Jackson, C. F., 78

Jackson, H. H. T., 281

Jenkins, H. O., 41

Jennings, W. L., 86

Jewett, S. G., 58, 274

$$
-\mathrm{K}-
$$

Kansas State College of Pittsburg, 111

Kansas State Teachers College, 337

Kansas State University, 112

Kearney State College, 170

Kirk, G. L., 263

Kirn, A. J., 246

$$
-\mathrm{L}-
$$

Lake Mead National Recreation Area, 345

Lake Superior State College, 143

Lassen Volcanic National Park, 313

Latham, R. C., 191

Layne, J. N., 86

Leffler, S. R., 269

Lister, R., 1

Llewellyn, L., 268

Los Angeles County Museum, 314

Louisiana

State University, 122

Tech University, 123

Loukashkin, A. S., 41

Lovejoy, D. A., 133

Luther College, 105

Lyndon State College, 264

$$
-\mathrm{M}-
$$

Manitoba Museum of Man and Nature, 4 Marshall University, 279

McGill University, 19 
Merriam, C. H., 81

Miami University, 201

Michigan

State University, 144

Technological University, 145

Mickey, A. M., 114, 288

Midwestern University, 238

Miller, D. H., 378

Miller, L. H., 68

Milwaukee Public Museum, 281

Mississippi

Museum of Natural Science, 157

State College for Women, 26

State University, 158

Missouri Department of Conservation, 340

Mohonk Museum, 190

Montana State University, 165

Moore, J. C., 86

Moore, J. E., 1

Mountain Lake Biological Station, 266

Mount Rainier National Park, 274

Mumford, R. E., 100

Munro, J. A., 17

Murie, O. J., 287

Museo Nacional, 299

Museum of Northern Arizona, 32

Museum of Science and Natural History, 341

$$
-\mathrm{N}-
$$

National Marine Fisheries Service, 270

National Museum of Natural History, 81

National Museum of Natural Science, 15

Natural History Museum of the Burpee Art Gallery Association, 332

Naval Arctic Research Laboratory, 28

Nevada State Museum, 175

New Brunswick Museum, 7

New Mexico

Environmental Improvement Agency, 181

State University, 182

New York

State Department of Environmental Conservation, 351

State Museum and Science Service, 191

North Carolina

State Museum, 194

State University, 195

North Dakota State University, 197

Northern Arizona University, 33
Northeastern State College, 208

Northeast Louisiana University, 124

North Texas State University, 239

Northwestern State University of Louisiana, 125

Northwest Missouri State University, 161

Nova Scotia Museum, 10

$$
-\mathrm{O}-
$$

Occidental College, 55

Ogden, H. V., 283

Ohio

Historical Society, 361

State University, 202

University, 203

Okanagan Museum and Archives Association, 292

Oklahoma State University, 209

Olson, A. C., Jr., 59

Olympic National Park, 271

Ontario Agricultural College, 295

Oregon State University, 215

Organ Pipe Cactus National Monument, 34

Osgood, F. L., 78

$$
-\mathrm{P}-
$$

Pacific Luthern College, 383

Pacific Union College, 56

Padovan, D. L., 272

Palmer, R. S., 132

Pan American University, 240

Panhandle Plains Historical Museum, 241

Park Museum, 364

Paul, J. R., 93

Peabody Museum, 134

Peabody Museum of Natural History, 326

Pennsylvania State University, 220

Petrified Forest National Monument, 305

Pettigrew Museum, 366

Philadelphia Academy of Natural Science, 221

Point Reyes National Seashore, 315

Price, W. W., 41

Princeton University, 179

Pruitt, W. O., 29

Purdue University, 100

$$
-Q-
$$

Quay, W. B., 283

Queen's University, 296

Quetico Provincial Park Museum, 297 


$$
-\mathrm{R}-
$$

Racey, K., 2

Rausch, R., 274

Reading Public Museum and Art Gallery, 222

Rhoads, S. N., 221

Richardson, C., 216

Richardson, W. B., 316

Riding Mountain National Park, 293

Riverside Municipal Museum, 317

Rocky Mountain Biological Laboratory, 73

Rocky Mountain National Park, 74

Rondeau Provincial Park, 16

Rose Lake Wildlife Research Center, 144

Roslyn Museum of Natural History, 356

Rowan, W., 1

Royal Ontario Museum, 17

$$
-\mathrm{S}-
$$

Saguaro National Monument, 306

Sam Houston State University, 372

San Bernardino

County Museum, 57

Valley College, 318

San Diego

Natural History Museum, 58

State University, 59

San Francisco State University, 60

Santa Barbara Museum of Natural History, 61

Saunders, W. D., 17

Savage, H., 298

Schorger, A. W., 283

Schwartz, A., 84

Scott, T., 104

Scriver, B., 166

Scull, M., 221

Seton, E. T., 183

Seton Memorial Library and Museum, 183

Shelton, A. C., 217

Shenandoah National Park, 267

Sherman, H. B., 86

Shippensburg State College, 223

Silliman, O. P., 64

Sinclair, J. G., 270

Smith, D. A., 13

Snyder, W. E., 283

Soper, J. D., 1

South Dakota

Department of Game, Fish, and Parks, 367

State University, $22^{-}$
Southeastern Louisiana University, 126

Southeastern State College, 210

Southern Illinois University-Carbondale, Cooperative Wildlife Research

Laboratory, 334

Department of Zoology, 95

Southern Illinois University-Edwardsville, 333

Southern Methodist University, 373

Southern Oregon College, 216

Southwestern College, 113

Southwestern Research Station, 35

Spencer, D. A., 75

Springfield Science Museum, 135

Stager, K. E., 314

Stanford University, 41

Starrett, A., 314

State Department of Social and Health Services, 273

State Game and Fish Commission, 369

State of Nebraska Game, Forestation, and Parks Commission, 343

State of Washington, 384

State University College of Education, Albany, 354

Plattsburgh, 355

State University of New York, Oneonta, 192

Syracuse, 193

St. Bonaventure University, 353

Stephen F. Austin State University, 374

St. Francis Community Junior-Senior High School, 114

St. John's University, 152

St. Vincent College, 363

Sul Ross State University, 242

Sumner, F. B., 64

$$
-\mathrm{T}-
$$

Tall Timbers Research Station, 85

Tarleton State University, 243

Taylor, E. H., 96

Tennessee, G., 122

Test, F. H., 146

Texas

A \& I University, 244

A \& M University, 245

Memorial Museum-University of Texas at Austin, Texas Natural History Collection, 246

Memorial Museum-University of Texas at Austin, Vertebrate Paleontology Laboratory, 247 
Tech University, 248

Wesleyan College, 249

The Science Museum of Minnesota, 153

Timpanogos Cave National Monument, 258

Trinity College, 327

Tulane University, 127

Tuttle, M. D., 115

$$
-\mathrm{U}-
$$

Union College, 344

Union Free School, 357

U.S. Bureau of Sport Fisheries and Wildlife, Denver Collection of the Bird and Mammal Laboratories, 76

U.S. Forest Service,

Glendora Research Center, 319

San Joaquin Experimental Range, 62

Universidad Nacional Autónoma de México, 23

University of

Alabama, 25

Alaska Museum, 29

Alberta, 1

Arizona, Arizona Archaeological Center, 36

Arizona, Department of Biological Sciences, 37

Arkansas, 39

Arkansas at Little Rock, 40

British Columbia, 2

California, Berkeley, Department of Zoology, 63

California, Berkeley, Museum of Vertebrate Zoology, 64

California, Davis, Department of Anatomy, 65

California, Davis, Museum of Wildlife and Fisheries Biology, 66

California, Davis, Museum of Zoology, 67

California, Los Angeles, 68

Cincinnati, 360

Colorado Museum, 75

Connecticut, 78

Delaware, 80

Florida, 86

Georgia, 88

Idaho, 329

Illinois, 96

Iowa, 106

Kansas, 115

Kentucky, 120
Maine, Department of Zoology, 129

Maine, School of Forest Resources, 130

Maine-Farmington, 339

Manitoba, 5

Massachusetts, Department of Forestry and Wildlife Management, 136

Massachusetts, Museum of Zoology, 137

Michigan, Department of Zoology, 147

Michigan, Laboratory of Vertebrate Biology, 148

Michigan, Museum of Zoology, 148

Michigan-Flint, 149

Minnesota, Department of Entomology, Fisheries, and Wildlife, 154, 155

Minnesota, James Ford Bell Museum of Natural History, 155

Minnesota-Duluth, 156

Missouri, 162

Montana, 167

Nebraska, 171

Nevada, Las Vegas, 176

Nevada, Reno, 346

New Hampshire, 178

New Mexico, 184

North Dakota, 198

Northern Colorado, 322

Northern Iowa, 107

Oklahoma, 211

Oregon, 217

Puerto Rico, 225

Puget Sound, 274

Saskatchewan-Regina, 20

Saskatchewan-Saskatoon, 21

South Alabama, 26

South Dakota, 228

South Florida, 87

Southwestern Louisiana, 128

Tennessee, 230

Texas at Arlington, 250

Texas at Austin, Laboratory of Physical Anthropology, 251

Texas at El Paso, 252

Tulsa, 212

Utah, 259

Vermont, 266

Virginia, 380

Washington, 275

Western Ontario, 18

West Virginia, 219

Wisconsin-Madison, Department of Wildlife Ecology, 282

Wisconsin-Madison, Zoological $\mathrm{Mu}$ seum, 283 
Wisconsin-Milwaukee, 284

Wisconsin-Stevens Point, 285

Wyoming, 288

Utah

Field House of Natural History, 376

State University, 260

$$
-\mathrm{V}-
$$

Velich, R., 172

Virginia Polytechnic Institute and State University, 268

Von Bloeker, J. C., 48

$$
-\mathrm{W}-
$$

Wagner Free Institute of Science, 224

Wake Forest University, 196

Walker, A., 215, 218

Walla Walla College, 276

Walnut Canyon National Monument, 307

Warren, E. R., 71, 75

Washington

Game Department, 274, 277

State University, 278

Watchung Reservation, 347

Wayne State University, 150

Weber State College, 261

Welder Wildlife Foundation, 254
Western Illinois University, 97

Western Kentucky State College, 338

Western New Mexico University, 185

Western State College, 77

Westfield State College, 138

West Texas State University, 375

Whitaker, J. O., Jr., 99

White Sands National Monument, 349

Whiteshell Nuclear Research Establishment, 6

Whitman College, 385

Whitney, N. R., 229

Wichita Mountains Wildlife Refuge, 362

Wichita State University, 116

William Jewell College, 342

Wilson, N., 107

Wind Cave National Park, 368

Winters, D. B., 320

Wisconsin Conservation Department, 387

Wistar Institute, 221

$$
-\mathrm{Y}-
$$

Yellowstone National Park, 289

Yosemite National Park, 69

$$
-\mathrm{Z}-
$$

Zion National Park, 377

\section{ACKNOWLEDGMENTS}

We especially acknowledge the cooperation of the other members of the American Society of Mammalogists' Advisory Committee for Systematic Resources on Mammalogy, and Past President of the Society, J. Knox Jones, Jr.

Numerous unnamed persons supplied information on the whereabouts of collections not included in previous lists. The survey was funded in part by a grant (GB 37737) from the National Science Foundation, and funds for clerical assistance and mailing charges were provided by the Department of Biological Sciences at Fort Hays Kansas State College. Last, but certainly not least, we are grateful to all the persons who completed and returned the questionnaire.

\section{LITERature Cited}

Advisory Committee for Systematic Resources in Mammalogy. 1974. Report and Recommendations. ... Processed by The Graduate School, Texas Tech Univ., $30 \mathrm{pp}$. (Available from Jerry R. Choate, Museum of the High Plains, Fort Hays Kansas State College, Hays, Kansas 67601).

Anderson, S., J. K. DoutT, ANd J. S. Findley. 1963. Collections of mammals in North America. J. Mamm., 44:471-500.

Doutt, J. K., A. B. Howell, And W. B. Davis. 1945. The mammal collections of North America. J. Mamm., 26:231-272.

Howell, A. B. 1923. The mammal collections of North America. J. Mamm., 4:113-120.

Museum of the High Plains, Fort Hays Kansas State College, Hays, 67601, and The Museum, Texas Tech University, Lubbock, 79409. 